\title{
CALCIUM AND VITAMIN D IN BONE FRACTURE HEALING AND POST-TRAUMATIC BONE TURNOVER
}

\author{
V. Fischer ${ }^{1}$, M. Haffner-Luntzer ${ }^{1}$, M. Amling ${ }^{2}$ and A. Ignatius ${ }^{1, *}$ \\ ${ }^{1}$ Institute of Orthopaedic Research and Biomechanics, Ulm University, Trauma Research Centre Ulm, \\ Ulm, Germany \\ ${ }^{2}$ Department of Osteology and Biomechanics, University Medical Centre Hamburg-Eppendorf, \\ Hamburg, Germany
}

\begin{abstract}
Calcium and vitamin D are essential for maintaining bone health. Therefore, deficiencies in calcium and vitamin D are major risk factors for osteoporosis development. Because sufficient amounts of calcium are also required for fracture-callus mineralisation, compromised bone repair that is frequently observed in osteoporotic patients might be attributed to calcium and vitamin D deficiencies. Consequently, calcium and vitamin D supplementation represents a potential strategy for treating compromised fracture healing in osteoporotic patients. Growing clinical evidence suggests that a fracture event may induce post-traumatic bone loss in the non-fractured skeleton, particularly in osteoporotic patients, which might further exacerbate osteoporosis and increase the risk of secondary fractures. Because the skeleton represents the main source of calcium, which is increasingly required during fracture-callus mineralisation, post-traumatic calcium mobilisation might occur under conditions of insufficient calcium and vitamin D status. However, to date, investigations of the roles of calcium and vitamin $\mathrm{D}$ in bone repair and post-traumatic bone turnover are very limited.

The current review summarises the state of the literature, focusing on the role of calcium and vitamin D in fracture healing and post-traumatic bone turnover, and critically discusses the therapeutic potential of calcium and vitamin D supplementation in this context.
\end{abstract}

Keywords: Calcium, vitamin D, fracture healing, post-traumatic bone loss, osteoporosis.

*Address for correspondence: Prof. Anita Ignatius, DVM, Institute of Orthopaedic Research and Biomechanics, University of Ulm, Helmholtzstraße 14, 89081 Ulm, Germany.

Telephone number: +4973150055301 Fax number: +4973150055302 Email: anita.ignatius@uni-ulm.de

Copyright policy: This article is distributed in accordance with Creative Commons Attribution Licence (http://creativecommons.org/licenses/by-sa/4.0/).

\section{List of abbreviations}

1,25-VitD
25-VitD
Alpl
ASBMR

BGLAP

BMD

Cckbr

CYP24A1 1,25-dihydroxy-vitamin- $\mathrm{D}_{3}$ 25-hydroxy-vitamin- $\mathrm{D}_{3}$ alkaline phosphatase American Society of Bone and Mineral Research bone gamma-carboxyglutamate protein bone mineral density cholecystokinin gastrin B receptor cytochrome P450 family 24 subfamily A member 1
FGF23

IL

IOF

OPG

OVX

PTH

RANK

RANKL

SPP1

TNFSF11

VDR fibroblast growth factor 23 interleukin International Osteoporosis Foundation osteoprotegerin ovariectomised parathyroid hormone receptor activator of NF- $\kappa B$ RANK ligand secreted phosphoprotein 1 tumour necrosis factor superfamily member 11 vitamin $\mathrm{D}$ receptor 


\section{Introduction}

Osteoporosis is globally the most common age-related skeletal disease, characterised by a progressive decline in bone mass and disruption of the bone micro-architecture, resulting in an increased risk of fragility fractures. Numerous risk factors influence osteoporosis development, including oestrogen decline during menopause, immobilisation, old age and nutrition (Rachner et al., 2011). In respect to nutrition, major osteoporosis risk factors are an insufficient calcium supply and a reduced vitamin D status. Calcium is the main mineral present in bones, where it provides skeletal strength and serves as a reservoir for maintaining blood calcium levels in a physiological range. Vitamin D is the key controller of calcium homeostasis by regulating intestinal calcium absorption, renal calcium reabsorption and bone remodelling (Amling et al., 1999; Li et al., 1997). Both calcium and vitamin $\mathrm{D}$ deficiencies promote bone loss through increased bone resorption in order to maintain the blood calcium concentration (Lips and van Schoor, 2011; Peacock, 2010). Vitamin D deficiency is recognised as a global health problem and is expected to increase further because of demographic changes reflecting an aging population (Hosseinnezhad and Holick, 2013). Because of the important roles of calcium and vitamin D in bone health, basic osteoporosis therapy includes their supplementation for individuals at high risk of osteoporosis, including aged postmenopausal females, when dietary calcium and vitamin D intake are insufficient (Cosman et al., 2014). However, osteoporosis treatment is rarely applied in clinics because osteoporosis is a silent disease, which is primarily diagnosed after patients have experienced the first fragility fracture. Even after such a fracture, under-treatment is common, because only $10-20 \%$ of patients receive adequate treatment (Bellantonio et al., 2001; Follin et al., 2003).

Both calcium and vitamin D play key roles in bone mineralisation, which is also part of the fracturehealing process (Claes et al., 2012; Einhorn and Gerstenfeld, 2015). Therefore, it is likely that calcium and vitamin D deficiencies contribute to fracturehealing complications, which are frequently observed in osteoporotic, postmenopausal patients (Nikolaou et al., 2009). However, only limited experimental and even fewer clinical studies investigate the role of calcium and vitamin D in fracture healing, as reviewed here. In addition, only a few investigate post-traumatic changes in the non-fractured skeleton, particularly under calcium- and vitamin-D-deficient conditions. There is growing clinical evidence of systemic bone loss following a fracture, as indicated by a reduction in the total bone mass of 2-15\%, compared to values immediately post-fracture or age-matched controls without fracture (Fox et al., 2000; Karlsson et al., 2000). Systemic bone loss may explain the clinical observation of an increased risk of secondary fractures (Ahmed et al., 2013; Lyles et al., 2008). Experimental data suggest that calcium and vitamin $\mathrm{D}$ deficiencies might exacerbate posttraumatic bone loss (Fischer et al., 2017; HaffnerLuntzer et al., 2016). Hereby, calcium, which is required for fracture-callus mineralisation, is increasingly mobilised from the remote skeleton to guarantee sufficient bone repair since the dietary calcium supply does not meet calcium requirements for callus mineralisation. These findings imply a clinical therapeutic requirement for calcium and vitamin D supplementation after fracture.

The scope of the current review was to summarise and analyse the known experimental and clinical data on the role of calcium and vitamin D in regular and osteoporotic fracture healing, as well as in posttraumatic bone turnover. Moreover, the therapeutic potential of calcium and vitamin D supplementation in the clinic, in particular in the prevention of fracturehealing complications and post-traumatic bone loss, is discussed based on the reviewed literature.

\section{Bone remodelling}

Bone is dynamically remodelled throughout the entire lifespan to replace damaged bone and adapt to mechanical load by the balanced and coupled actions of bone-forming osteoblasts and boneresorbing osteoclasts. Balanced bone remodelling is essential for the maintenance of bone mass and skeletal integrity. The complex process of bone remodelling is regulated by a variety of endogenous and exogenous factors. Primarily, it is regulated through the RANK/RANKL/OPG system acting directly on osteoblast/stroma cells and osteoclast precursors. RANKL, expressed by osteoblasts/stroma cells, binds to the RANK receptor on osteoclast precursors inducing osteoclastogenesis (Suda et al., 1999). Osteoblast-produced OPG functions as a decoy receptor, blocking the effects of RANKL (Hsu et al., 1999). Many local and systemic factors regulating bone remodelling - including transforming growth factor- $\beta$, bone morphogenic proteins, cytokines-like IL-1 $\beta$, IL- 6 and tumour necrosis factor- $\alpha$, hormones such as PTH, 1,25-VitD 3 and oestrogen - mainly signal by influencing the RANK/RANKL/OPG system on osteoblasts/stroma cells, thus keeping the system in balance (Crockett et al., 2011). In addition to these endogenous determinants, exogenous factors, including mechanical loading and nutrition, are involved. Osteocytes sense and respond to mechanical stimuli by the induction of osteo-anabolic signals, including nitric oxide and prostaglandins (Robling et al., 2006). Calcium and vitamin D are the main nutrients exerting important functions in bone remodelling (Gennari, 2001).

Imbalances in bone remodelling can drive bone metabolism towards increased bone formation, favouring abnormal bone gain, as seen in osteosclerosis, or towards increased bone resorption, resulting in bone loss, as observed in osteoporosis. 


\section{Calcium and vitamin D involvement in bone remodelling and homeostasis}

Dietary composition, in particular, the amounts of calcium and vitamin $\mathrm{D}$, play an important role in bone remodelling and skeletal integrity (Gennari, 2001). Approximately $99 \%$ of the body's calcium is present in bones and teeth, stored as hydroxyapatite responsible for tissue mineralisation. In bone, it provides skeletal strength and serves as a calcium reservoir to maintain constant blood calcium levels. Therefore, calcium is required for skeletal growth, development and maintenance. Calcium requirements differ during the lifetime, depending on the varying needs due to growth in childhood and youth, or during pregnancy and lactation (Nordin, 1997). Calcium as an essential element is only available through the diet. However, dietary calcium recommendations vary widely among countries. For example, the recommended daily calcium intake for the elderly above 65 years in Germany is $1000 \mathrm{mg}$, in the USA $1200 \mathrm{mg}$ and in the UK $700 \mathrm{mg}$ (German Nutrition Society, 2013; Institute of Medicine, 2011; Prentice, 2013). Differences might arise from variations in data acquisition and interpretation and cultural aspects, including geographic locations, lifestyle and genetics. Under physiological conditions, approximately 30$40 \%$ of the ingested calcium is absorbed by the gut. Several factors influence calcium absorption rate, including total calcium amount, nature of the calcium complex, acidic conditions in the stomach and small intestine, age and vitamin D status (Fleet, 2017; Krause et al., 2015; Schinke et al., 2009). In the case of high dietary calcium intake, calcium is absorbed by passive diffusion. By contrast, normal to low dietary calcium intake requires active calcium absorption, which is regulated by the active $1,25-\mathrm{VitD}_{3}$ acting on the VDR in the intestine (Christakos et al., 2014). Therefore, vitamin $\mathrm{D}$ plays a key role in calcium and bone homeostasis.

The fat-soluble vitamin D (cholecalciferol) is ingested as part of the diet or is synthesised in the skin upon ultraviolet-B irradiation (Holick et al., 1980). To acquire physiologic activity, vitamin D is firstly hydroxylated in the liver on carbon 25 by 25-hydoxylase, producing 25-VitD 3 (calcifediol). In the kidney, $25-\mathrm{VitD}_{3}$ is secondly hydroxylated on carbon 1 by a $1-\alpha$-hydroxylase, producing the biologically active $1,25-\mathrm{VitD}_{3}$ (calcitriol). In the target tissues, $1,25-\mathrm{VitD}_{3}$ binds to its nuclear VDR, a family member of the steroid/thyroid hormone receptors, and functions as a transcription factor. As a heterodimer mainly bound to the retinoid-X-receptor, the VDR binds to vitamin $D$ response elements on the DNA, thus modulating the transcription of numerous vitamin $\mathrm{D}$ target genes, including the bone-related genes osteocalcin (BGLAP), osteopontin (SPP1) and RANKL (TNFSF11). The VDR is expressed by most mammalian organs and their respective cell types, including the immune system, gastro-intestinal tract, reproductive organs, kidney, parathyroid gland, skin, heart, brain, muscles and bones, thus suggesting a broad variety of biological functions (Christakos et al., 2016). However, the key function of $1,25-\mathrm{VitD}_{3} / \mathrm{VDR}$ is the regulation of mineral and bone homeostasis $(\mathrm{Li}$ et al., 1998).

1,25-VitD ${ }_{3}$ PTH and FGF23 (a key regulator of phosphate and vitamin D metabolism) are the main factors maintaining constant blood calcium and phosphate levels by regulating: i) calcium and phosphate absorption in the intestine and reabsorption in the kidney, ii) bone resorption. The main inducer of this complex regulatory network is a change in serum calcium levels, since constant calcium concentrations are essential for many biological functions. The inactivation of the calcium-sensing receptor in the parathyroid glands, resulting from a fall in serum calcium levels, stimulates PTH release (Fig. 1). Circulating PTH binds to its receptor in the kidney, where it enhances calcium reabsorption, phosphate excretion and $1,25-\mathrm{VitD}_{3}$ production. Both circulating $\mathrm{PTH}$ and $1,25-\mathrm{VitD}_{3}$ bind their respective receptors on osteoblasts, thus increasing RANKL expression, which stimulates osteoclastic bone resorption and the release of calcium and phosphate into the circulation. Consequently, calcium levels are restored and negative feedback mechanisms are induced, including the release of calcitonin from the thyroid gland, which reduces calcium reabsorption in the kidney and absorption in the gut and inhibits osteoclastic bone resorption, thus maintaining calcium levels in a physiological range (Fig. 1).

The parallel increase of phosphate levels during the calcium-mediated PTH and 1,25-VitD ${ }_{3}$ actions requires the phosphate-lowering actions of FGF23, independent of PTH (Fig. 1). The 32 kDa FGF23, which belongs to the FGF19 subfamily, is increasingly released by osteocytes in bones upon high circulating phosphate and 1,25-VitD $\mathrm{D}_{3}$ concentrations (Liu et al., 2006). In the kidney, FGF23, associated with its cofactor Klotho, binds the FGF1 receptor, thus decreasing renal phosphate reabsorption and increasing its excretion (Urakawa et al., 2006). In addition, FGF23 further reduces phosphate levels by inhibiting $1,25-\mathrm{VitD}_{3}$ production in the kidney and probably $\mathrm{PTH}$ production in the parathyroid gland (Ben-Dov et al., 2007; Shimada et al., 2004). Several inherited syndromes characterised by abnormalities in FGF23 levels are associated with osteomalacia, thus strengthening the role of FGF23 in bone homeostasis (Shimada et al., 2001; Weber et al., 2003; Yamazaki et al., 2002). In addition, as shown in experimental and clinical studies, genetic Klotho deficiency is associated with reduced bone mass (Kuro-o et al., 1997; Yamada et al., 2005; Zarrabeitia et al., 2007). In contrast, studies investigating associations of serum Klotho and bone mass report controversial results (Baldan et al., 2015; Chalhoub et al., 2016). In osteoporotic elderly, no associations between serum Klotho and bone loss and fracture risk are detected (Chalhoub et al., 2016). Since the membranebound Klotho protein, which is required for FGF23 function in bone, is not measurable in the blood, the 
relevance of the secreted Klotho protein as a marker for osteoporosis is uncertain and needs to be further examined.

In conclusion, the process of bone remodelling is essential for adapting to the changes in calcium levels. However, a low dietary calcium supply or longlasting vitamin D deficiency, which considerably reduces intestinal calcium absorption and increases PTH concentrations, stimulates bone turnover and excessive bone resorption to restore systemic calcium levels. These mechanisms favour bone loss and osteoporosis development.

\section{Calcium and vitamin D in osteoporosis}

Osteoporosis is globally the most common skeletal disease, affecting alone in Europe, USA and Japan an estimated 75 million people, as stated by the IOF in 1997 (Consensus Development Conference, 1997). Due to demographic changes of an aging population, the number has increased in the last decades and will further increase in the future. In 2010, an estimated number of 53.6 and 27.5 million people suffered of osteoporosis in the USA and Europe, respectively (Hernlund et al., 2013; Wright et al., 2014). The IOF estimates that more than 200 million women

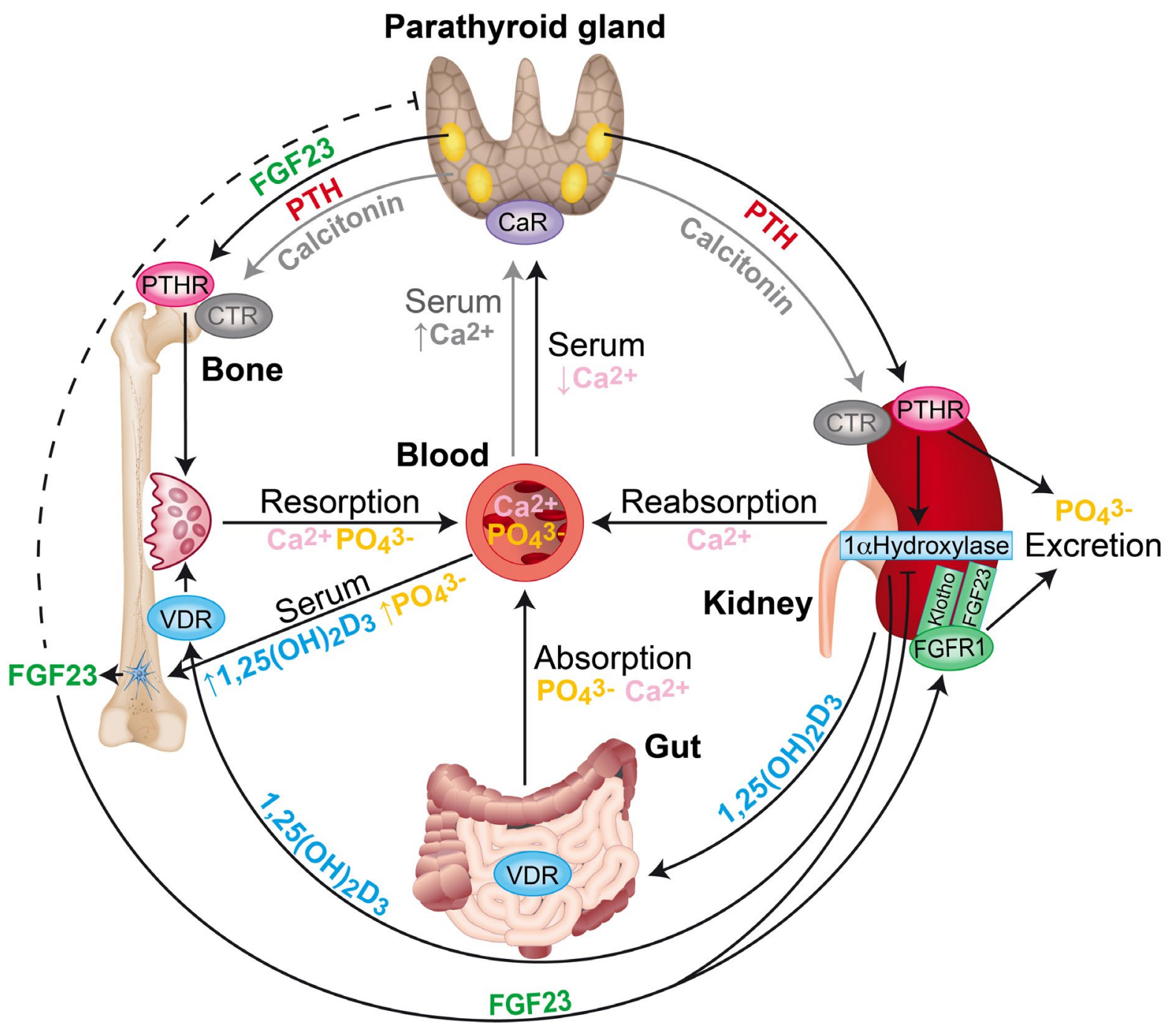

Fig. 1. Regulation of calcium and bone homeostasis. Upon a fall in serum calcium, PTH is secreted from the parathyroid glands. Circulating PTH increases calcium mobilisation from bones and stimulates both calcium reabsorption and $1,25-\mathrm{VitD}_{3}$ synthesis in the kidneys. 1,25- $\mathrm{VitD}_{3}$ increases calcium absorption in the gut. In response to $\mathrm{PTH}$ and 1,25-VitD 3 actions, phosphate levels increase, stimulating FGF23 secretion from bone osteocytes. In the kidney, FGF23 promotes phosphate excretion and inhibits 1,25-VitD production. FGF23 might further inhibit PTH secretion. Restored/high serum calcium levels trigger negative feedback loops, including calcitonin acting on its own receptor, thus reducing renal calcium reabsorption and inhibiting osteoclastic bone resorption (illustrated in bright grey). $\mathrm{Ca}=$ calcium; $\mathrm{PO}=$ phosphate; $\mathrm{PTH}=$ parathyroid hormone; $1,25-(\mathrm{OH})_{2} \mathrm{D}_{3}=1,25$-dihydroxy-vitamin $\mathrm{D}_{3} ; \mathrm{FGF} 23$ = fibroblast growth factor 23; $\mathrm{VDR}=$ vitamin $\mathrm{D}$ receptor; $\mathrm{PTHR}=$ parathyroid hormone receptor; FGFR1 = fibroblast growth factor receptor $1 ; \mathrm{CaR}=$ calcium sensing receptor; $\mathrm{CAR}=$ calcitonin receptor. 
worldwide suffer from osteoporosis (Kanis, 2007). The disease is characterised by a progressive decline in bone mass and disruption of bone microarchitecture because of the unbalanced activities of osteoclasts and osteoblasts, where bone resorption exceeds bone formation. According to the World Health Organization, osteoporosis is defined by a reduction in BMD of 2.5 or more standard deviations below the mean BMD of young adults (Cosman et al., 2014). Osteoporosis is associated with an increased risk of fragility fractures, mainly occurring at the spine, hip and wrist. The lifetime risk of an osteoporotic fracture is $40 \%$ in females versus $27 \%$ in males (Cooley and Jones, 2001; Kanis et al., 2000). The most common form is postmenopausal osteoporosis, which results from a decline in oestrogen levels because of menopause, and globally affects an estimated 200 million females (Kanis, 2007). Overall, a panel of risk factors, including genetics, gender, age, comorbidities and their therapies, life style and nutrition influence osteoporosis development.

Calcium and vitamin D deficiencies represent the main risk factors influencing osteoporosis development. Changes in serum calcium entail adaptations in bone remodelling, as in the case of increased bone resorption induced by low serum calcium. With a mean daily calcium intake of approximately 700-800 mg in adults in Germany (European Food Safety Authority, 2006), the calcium supply remains slightly below the recommendation of $1000 \mathrm{mg} / \mathrm{d}$ (German Nutrition Society, 2013). However, both intestinal calcium absorption and dietary calcium intake decrease with increasing age (Ireland and Fordtran, 1973; Wakimoto and Block, 2001). Such low-to-normal dietary calcium intake requires active intestinal transport by 1,25VitD $_{3}$ (McCormick, 2002). However, vitamin D deficiency is common (Holick and Chen, 2008). One main reason is the low dietary vitamin D intake, because only a few foods have a high vitamin $\mathrm{D}$ content, including oily fish, eggs, milk and some dairy products. Because eating habits change with age, the lowest vitamin D supply from the diet is in those above 65 years (Wakimoto and Block, 2001). However, endogenous vitamin D synthesis in the skin upon sunlight exposure supplies $80-90 \%$ of the required vitamin D. Nevertheless, numerous factors, including geographic location, latitude, season, time spent outdoors and clothing, influence dermal vitamin D synthesis. For example, solar irradiation during winter is insufficient to produce vitamin D in people resident in northern countries (Webb et al., 1988). To guarantee optimal bone metabolism and bone health, systemic $25-\mathrm{VitD}_{3}$ levels of $75 \mathrm{nmol} / \mathrm{L}$ or more $(>30 \mathrm{ng} / \mathrm{mL}$ ) are required, because lower $25-$ VitD $_{3}$ concentrations are associated with bone mineralisation defects (Priemel et al., 2010; von Domarus et al., 2011). Globally, it is estimated that vitamin D deficiency affects approximately 3 billion people (Hossein-nezhad and Holick, 2013). In Europe, roughly $80 \%$ of the population displays insufficient
25-VitD ${ }_{3}$ serum levels below $75 \mathrm{nmol} / \mathrm{L}(<30 \mathrm{ng} /$ mL) (Gonzalez-Gross et al., 2012; Holick et al., 2011). Particularly in Germany, widespread vitamin D deficiency is common and occurs through all ages (Hintzpeter et al., 2008a; Hintzpeter et al., 2008b). However, the effects are even more pronounced in the elderly (Schilling, 2012), due to reduced dermal vitamin D-synthesis capacity with age (MacLaughlin and Holick, 1985) and reduced sunlight exposure because of immobility and less time spent outdoor (Bruyere et al., 2014; Holick et al., 1980). Indeed, in Germany, the mean 25-VitD levels are $46.2 \mathrm{nmol} / \mathrm{L}$ in adults and $39.1 \mathrm{nmol} / \mathrm{L}$ over 65 years (German Nutrition Society, 2012). Particularly in risk groups, including elderly and postmenopausal females, severe vitamin $\mathrm{D}$ deficiency might interfere with bone health, because of reduced intestinal calcium absorption capacity. Indeed, several epidemiological studies demonstrate associations between low 25VitD 3 levels and reduced bone mass on one side and increased risk of falls and fragility fractures on the other (Bischoff-Ferrari et al., 2014; Kuchuk et al., 2009). Therefore, preventive and therapeutic actions, including nutrient supplementation and food fortification, ensuring minimum circulating 25VitD 3 levels $(75 \mathrm{nmol} / \mathrm{L}$ or $30 \mathrm{ng} / \mathrm{mL}$ ) are required to preserve and restore bone health (Brown et al., 2013a; Brown et al., 2013b).

For osteoporosis and fracture prevention, practical guidelines of the National Osteoporosis Foundation recommend calcium and vitamin D supplementation for high-risk groups, including postmenopausal females (> 50 years old), when dietary calcium and vitamin D intake is insufficient (Cosman et al., 2014). In addition, calcium and vitamin D supplementation is, as basal therapy, always part of other osteoporosis treatments, including bisphosphonates, intermittent PTH application or novel drugs targeting sclerostin, RANKL or cathepsin K (Rachner et al., 2011; Tabatabaei-Malazy et al., 2017). However, the efficiency and safety of calcium, vitamin D or combined calcium and vitamin D supplementations are critically discussed. On the one hand, several clinical trials observe a reduction in hip and non-vertebral fractures because of calcium and vitamin D supplementation (Bischoff-Ferrari et al., 2008; Bischoff-Ferrari et al., 2005; Chapuy et al., 1992; Warensjo et al., 2011). In addition, a metaanalysis by Tang et al. (2007) report that calcium and vitamin D supplementation reduce osteoporoticfracture occurrence, thus corroborating the beneficial effects of calcium and vitamin D supplementation on fracture risk reduction. On the other hand, some meta-analyses do not observe associations between calcium and vitamin D supplementation and fracture-risk reduction (Bolland et al., 2015; Peacock et al., 2000; Zhao et al., 2017). However, most of these studies are conducted in healthy communitydwelling adults, who clearly do not profit from calcium or vitamin D supplements. By contrast, risk groups of elderly, particularly postmenopausal 
females, displaying reduced calcium intake and insufficient vitamin D status benefit from calcium and vitamin D supplements (Harvey et al., 2017; Tang et al., 2007). Confirming this, a very recently published statement of the ASBMR warns of reports highlighting no beneficial effects of calcium and vitamin D supplementation in community-dwelling adults, because such meta-analyses frequently focus only on healthy adults. The ASBMR clearly state that these findings do not apply to osteoporotic patients or patients taking bone protective drugs, including bisphosphonates and PTH, because calcium and vitamin D supplementation, as a part of a basal therapy, influences drug efficiency and treatment success (Web ref. 1). However, a general populationbased treatment with calcium and vitamin D is not recommended, because beneficial health effects are, to date, not demonstrated (Harvey et al., 2017). Sufficient calcium and vitamin D should be obtained through the diet or skin synthesis. However, when this is not achievable, supplements are recommended for risk groups (Cosman et al., 2014). To exclude critically discussed and still scientifically unproven side effects of increased calcium levels due to supplementation - which might favour the development of kidney stones, cardiovascular diseases or gastrointestinal symptoms - patients with a history of these diseases should be monitored for serum parameters of calcium metabolism. However, the tolerable upper calcium limit posing no risk of adverse health effects for the general population is $2500 \mathrm{mg} / \mathrm{d}$, which is not reached by the dietary supply or calcium supplements, commonly containing 500-1200 mg of calcium (European Food Safety Authority, 2006).

Osteoporosis is frequently under-treated and under-diagnosed until patients have experienced the first osteoporotic fracture. Even after such a fracture, only $10-20 \%$ of patients receive adequate osteoporosis treatment, including calcium and vitamin D supplementations (Bellantonio et al., 2001; Follin et al., 2003; Weaver et al., 2017). The main reasons are a lack of diagnosis and therapy initiation, possibly because of side effects, uncertain efficiencies, high costs and patient's health status, compliance and motivation. In addition, the primary goal of trauma surgeons is fracture stabilisation and reduction, which might be one reason for the lack of diagnosis and treatment initiation (Weaver et al., 2017). Interdisciplinary approaches strengthening the collaboration of trauma surgeons, osteologists and nutritionists might reduce the existing therapy deficit, which may further reduce the risk of fragility fractures.

\section{Fracture healing}

Fractures caused by osteoporosis occur in one third of females and one fifth of males over 50 years. Globally, approximately 9 million people with osteoporosis suffer a fracture annually (Johnell and Kanis, 2006). Thus, because of ongoing demographic changes with an aging population, the incidence of fractures will further increase. Bone fractures normally heal without complications and any scar formation. However, under specific conditions, including old age, impaired health status, comorbidities and severe injuries/traumas, the repair process may fail (Claes et al., 2012). Therefore, a total of 5-10\% of all fractures display disturbed bone healing (Zura et al., 2016). Bone fracture healing is a highly dynamic, complex and tightly regulated process that involves the interplay of many cells and molecular mediators, including growth factors and cytokines, and is further influenced by the biomechanical environment of the fracture-healing zone. The repair process proceeds in three overlapping phases: inflammation, repair and remodelling. The inflammatory phase is characterised by tissue and cell damage, rupture of blood vessels and recruitment of immune cells to the fracture haematoma. During the repair phase, intramembranous and endochondral ossification drive fracture-callus formation and growth towards the fracture gap until bony bridging. During remodelling, the newly formed woven bone is replaced by lamellar bone, thus restoring the original bone structure and stability (Claes et al., 2012). The changes that occur with the onset of osteoporosis might interfere with this complex and tightly regulated repair process. Indeed, compromised bone repair is frequently observed in osteoporotic patients (Cornell et al., 2003; Nikolaou et al., 2009; Zura et al., 2016). However, pathomechanisms are still poorly understood and further research is needed.

\section{Osteoporotic fracture healing}

Osteoporotic fractures are more frequently associated with complications, including infections and implant failure, resulting in expensive aftercare with prolonged hospitalisation periods and increased morbidity and mortality rates. Implant failure occurs in approximately 10-25 \% of osteoporotic fracture cases (von Ruden and Augat, 2016). The total complication rate, not only including bonerelated complications but also infections, pneumonia and anaemia, is approximately $60 \%$ after hip and $50 \%$ after vertebral fractures and increases with age (Lehmann et al., 2016). Nikolaou et al. (2009) demonstrate that fracture-healing time is significantly prolonged in older osteoporotic patients, thus indicating a delay of the repair process. Furthermore, half of the osteoporotic patients do not fully recover after hip injury (Cornell et al., 2003). Epidemiological analysis show that the risk of fracture non-union is significantly increased in osteoporotic patients (Zura et al., 2016). Therefore, osteoporosis affects the boneregenerative capacity, resulting in fracture-healing complications. However, it is still strongly debated whether osteoporotic bones heal worse because of poor fixation stability in fragile bone or whether the 
Table 1. Summary of experimental and clinical studies on the effects of calcium and vitamin D on fracture healing. s.c.: subcutaneous; i.m.: intramuscular.

\begin{tabular}{|c|c|c|c|}
\hline Study and fracture type & Treatment & Fracture-healing outcome & Authors \\
\hline \multicolumn{4}{|c|}{ Experimental studies } \\
\hline $\begin{array}{l}\text { Male rats (age: } 2 \text { weeks) } \\
\text { hind leg fracture }\end{array}$ & $\begin{array}{l}\text { Calcium- and/or } \\
\text { phosphorus-deficient } \\
\text { diet }\end{array}$ & $\begin{array}{l}\text { Impaired healing: } \downarrow \text { callus } \\
\text { mineralisation }\end{array}$ & Doepfner, 1970 \\
\hline $\begin{array}{l}\text { Male rats } \\
\text { femur drill hole defect }\end{array}$ & $\begin{array}{c}\text { Injection (s.c.) of 1,25- } \\
\text { VitD }_{3}\end{array}$ & $\begin{array}{l}\text { Improved healing: } \uparrow \\
\text { biomechanical properties }\end{array}$ & Lindgren et al., 1981 \\
\hline $\begin{array}{l}\text { Male rats (age: mature) } \\
\text { femur fracture, } \\
\text { intramedullary fixation }\end{array}$ & $\begin{array}{l}\text { Calcium-/vitamin } \\
\text { D-deficient diet } \\
\text { Calcium-/vitamin } \\
\text { D-supplemented diet }\end{array}$ & $\begin{array}{l}\text { Regular healing } \\
\text { Regular healing }\end{array}$ & Einhorn et al., 1986 \\
\hline $\begin{array}{l}\text { Male guinea pigs } \\
\text { tibia fracture }\end{array}$ & $\begin{array}{l}\text { Single high-dose } \\
\text { injection (i.m.) of } \\
\text { vitamin D }\end{array}$ & $\begin{array}{l}\text { Improved healing: } \\
\uparrow \text { blood supply, } \\
\text { callus formation and } \\
\text { mineralisation }\end{array}$ & $\begin{array}{l}\text { Omeroglu et al., } \\
\text { 1997b }\end{array}$ \\
\hline $\begin{array}{c}\text { Male rabbits (age: } 3 \\
\text { months) } \\
\text { femur fracture, } \\
\text { intramedullary fixation }\end{array}$ & $\begin{array}{l}\text { Single high-dose } \\
\text { injection (i.m.) of } \\
\text { vitamin D }\end{array}$ & $\begin{array}{c}\text { Improved healing: } \uparrow \\
\text { biomechanical competence }\end{array}$ & $\begin{array}{l}\text { Omeroglu et al., } \\
1997 \mathrm{a}\end{array}$ \\
\hline $\begin{array}{c}\text { Male rats (age: } 18 \text { months) } \\
\text { femur fracture, } \\
\text { intramedullary fixation }\end{array}$ & $\begin{array}{l}\text { Injection (s.c.) of } \\
25-\text { VitD }_{3}\end{array}$ & $\begin{array}{c}\text { Improved healing: } \uparrow \\
\text { biomechanical competence }\end{array}$ & $\begin{array}{l}\text { Delgado-Marinez } \\
\text { et al., } 1998\end{array}$ \\
\hline $\begin{array}{c}\text { Female rats (age: } 2 \text { months) } \\
\text { ovariectomy, femur } \\
\text { fracture, intramedullary } \\
\text { fixation } \\
\end{array}$ & Calcium-deficient diet & $\begin{array}{c}\text { Impaired healing: } \downarrow \text { bone } \\
\text { content, biomechanical } \\
\text { properties }\end{array}$ & $\begin{array}{l}\text { Namkung-Matthai } \\
\text { et al., } 2001\end{array}$ \\
\hline $\begin{array}{c}\text { Male rats } \\
\text { Tibia fracture, } \\
\text { intramedullary fixation }\end{array}$ & $\begin{array}{l}\text { Injections (i.m.) of } \\
\text { calcium/vitamin D }\end{array}$ & $\begin{array}{l}\text { Improved healing: } \uparrow \\
\text { biomechanical properties }\end{array}$ & Aslan et al., 2006 \\
\hline $\begin{array}{c}\text { Female rats (age: } 10 \text { weeks) } \\
\text { ovariectomy, tibia fracture, } \\
\text { intramedullary fixation }\end{array}$ & Vitamin D-deficient diet & Regular healing & Melhus et al., 2007 \\
\hline $\begin{array}{c}\text { Female rats (age 6: months) } \\
\text { ovariectomy, femur } \\
\text { fracture, intramedullary } \\
\text { fixation }\end{array}$ & $\begin{array}{c}1,25-\mathrm{VitD}_{3} \\
\text { supplementation (oral } \\
\text { gavage) }\end{array}$ & $\begin{array}{c}\text { Improved healing: } \uparrow \\
\text { biomechanical properties, } \\
\text { bone content }\end{array}$ & Fu et al., 2009 \\
\hline $\begin{array}{c}\text { Female mice (age: } 26 \\
\text { weeks) } \\
\text { femur fracture, external } \\
\text { fixation }\end{array}$ & $\begin{array}{l}\text { Calcium deficiency due } \\
\text { to malabsorption } \\
\text { Calcium-supplemented } \\
\text { diet }\end{array}$ & $\begin{array}{c}\text { Regular healing } \\
\text { Improved healing: } \uparrow \\
\text { biomechanical properties, }\end{array}$ & $\begin{array}{c}\text { Haffner-Luntzer et } \\
\text { al., } 2016\end{array}$ \\
\hline $\begin{array}{c}\text { Female mice (age: } 26 \\
\text { weeks) } \\
\text { ovariectomy, femur } \\
\text { fracture, external fixation }\end{array}$ & $\begin{array}{c}\text { Calcium-/vitamin } \\
\text { D-deficient diet } \\
\text { Calcium-/vitamin } \\
\text { D-supplemented diet }\end{array}$ & $\begin{array}{c}\text { Regular healing } \\
\text { Improved healing: } \uparrow \\
\text { biomechanical properties }\end{array}$ & Fischer et al., 2017 \\
\hline \multicolumn{4}{|c|}{ Clinical studies } \\
\hline $\begin{array}{c}\text { Postmenopausal women } \\
(n=30 ; \text { mean age: } 78 \text { years }) \\
\text { randomised placebo- } \\
\text { controlled study, proximal } \\
\text { humerus fracture }\end{array}$ & $\begin{array}{l}\text { Calcium/vitamin D } \\
\text { supplementation }\end{array}$ & $\begin{array}{l}\text { Improved healing: } \uparrow \text { bone } \\
\text { content in fracture callus }\end{array}$ & Doetsch et al., 2004 \\
\hline
\end{tabular}


biological healing potential is reduced (Nikolaou et al., 2009). Clinical trials frequently highlight the surgical complications of osteoporotic fracture treatment, whereas experimental studies have the advantage of investigating the biological regeneration capacity and the fracture-healing outcome more reliably. During recent years, several experimental studies, mostly performed in OVX rodents, mimicking the clinical picture of oestrogen depletion after menopause, reveal a reduced regeneration potential during all stages of bone repair. This is indicated by a reduced amount of newly-formed bone and diminished biomechanical competence of the fracture callus (Meyer et al., 2001; Namkung-Matthai et al., 2001; Wang et al., 2005), as well as changes in angiogenesis (Sun et al., 2012), cartilage formation (Islam et al., 2005) and osteoblast and osteoclast functions in the fracture callus (Islam et al., 2005; Xu et al., 2004). Because osteoporosis is a multifactorial disease, the biological reasons for impaired bone repair are manifold, including a disturbed immune response after fracture (Haffner-Luntzer et al., 2017), disturbances in osteoanabolic signalling pathways (Heilmann et al., 2013; Ke et al., 2012; Xu et al., 2014) and changes in oestrogen levels and signalling (Beil et al., 2010; Haffner-Luntzer et al., 2018; Wehrle et al., 2015).

Many experimental studies report delayed and disturbed fracture healing in osteoporosis. However, the pathomechanisms of osteoporotic fracture healing are multifactorial and still poorly understood, thus needing further investigation. Regarding the increasing number of elderly, osteoporosis and fragility fractures, the identification of the mechanisms disturbing osteoporotic bone healing is of considerable clinical relevance for the development of new therapeutic strategies. Notably, the role of calcium and vitamin D in fracture healing in this context is, to date, poorly investigated.

\section{Calcium and vitamin D involvement in bone repair}

Because calcium and vitamin D play pivotal roles in bone remodelling and mineralisation and while mineralisation is an essential part of fracturecallus formation, both nutrients may influence the fracture-healing process. Calcium is essential for callus mineralisation: approximately $1.7-2.3 \mathrm{~g}$ of hydroxyapatite deposition is needed per $\mathrm{cm}^{3}$ of bony callus, as shown by determining calcium kinetics with radioactive $\mathrm{Ca}^{45}$ during callus development in rats (Bauer, 1954; Herman and Richelle, 1961; Lemaire, 1966). Therefore, it is likely that deficiencies in calcium and vitamin D negatively influence fracture healing. Notably, there is only a limited number of conflicting experimental studies, some published many decades ago, investigating the effect of calcium and/or vitamin D deficiency on fracture healing (Table 1). Some of these animal studies are already reviewed by Eschle and Aeschlimann (2011). Rats deficient in dietary calcium display a reduced fracture callus mineralisation, as shown by a lower callus weight (Doepfner, 1970). Similarly, osteoporotic rats with calcium deficiency exhibit diminished callus bone content, quality and biomechanical competence (Namkung-Matthai et al., 2001). By contrast, regular fracture healing is observed in calcium- and vitaminD-deficient rats (Einhorn et al., 1986), osteoporotic rats receiving a vitamin-D-deficient diet (Melhus et al., 2007) and mice displaying intestinal calcium malabsorption (Haffner-Luntzer et al., 2016). Differences in results may arise from the widely varying experimental conditions. In addition, only a few studies consider the aspect of osteoporosis/ oestrogen-deficiency. However, elderly patients with healing complications and non-unions are more frequently vitamin-D-deficient when compared to patients with uneventful bone regeneration (Di Monaco et al., 2006; Pourfeizi et al., 2013; Warner et al., 2016). Summarising these experimental and clinical data, the influence of calcium and vitamin $\mathrm{D}$ deficiency on bone repair is greatly debated and poorly investigated. More preclinical and clinical studies are needed.

Many more studies investigate the effects of calcium and vitamin D supplementation on fracture-healing (Table 1). Most of these studies are performed in rats that are injected with vitamin $D$ (cholecalciferol), 25-VitD 3 or 1,25-VitD 3 after fracture. Improved healing is observed, as indicated by improved biomechanical properties and increased bone content of the fractured bones (Aslan et al., 2006; Delgado-Martinez et al., 1998; Lindgren et al., 1981; Omeroglu et al., 1997a; Omeroglu et al., 1997b) as well as an accelerated fracture-callus remodelling after oral 1,25-VitD ${ }_{3}$ administration (Fu et al., 2009). By contrast, rats receiving a mineral-enriched diet containing calcium and vitamin D display a regular fracture healing (Einhorn et al., 1986). Haffner-Luntzer et al. (2016) observe improved fracture healing as demonstrated by increased flexural rigidity of the fractured femora and enhanced callus bone formation in mice fed with a calcium-supplemented diet. In agreement with these findings, fracture healing is also improved in OVX-mice that display chronic calcium and vitamin D deficiency before fracture when supplemented with calcium and vitamin D immediately after fracture occurrence (Fischer et al., 2017). These mice exhibit improved biomechanical fracture-callus properties and the highest percentage of bony-bridged fracture gaps, indicating successful fracture healing. Cellular parameters are also changed, because osteoclasts are reduced and osteoblasts increased in the calli of supplemented mice (Fischer et al., 2017). Corroborating these findings, a prospective, randomised placebo-controlled clinical study, with postmenopausal females receiving calcium and vitamin $\mathrm{D}$ after fracture, describe increased bone content in the fractured area 6 weeks after proximal humerus fracture because of supplementation, compared to placebo-receiving controls (Doetsch et al., 2004). However, this is currently the only clinical study investigating the fracture-healing outcome. In 
several clinical studies calcium and vitamin D are supplemented after fracture, but these studies focus on the effects on total BMD, fracture prevention or changes in serum bone parameters and not specifically on bone healing itself (Harwood et al., 2004; Kolb et al., 2013).

Most experimental and clinical studies support beneficial effects of calcium and vitamin D supplementation during bone repair. However, as previously reviewed by others, clinical studies addressing the effects of calcium and vitamin D on fracture healing are rare and data on beneficial effects remain inconclusive (Gorter et al., 2014; Sprague et al., 2016). Within the reviewed human studies, only a few investigate the fracture-healing outcome, whereas most only measured the effects of supplementation on changes in $25-\mathrm{VitD}_{3}$ levels. Therefore, more clinical placebo-controlled randomised trials are needed, in which patients, particularly with chronic calcium and vitamin D deficiency, are supplemented with both nutrients during the healing process and the fracture-healing outcome is evaluated.

Both indirect and direct effects of calcium and vitamin D in bone repair are discussed. Fischer et al. (2017) observe improved calcium balance as shown by reduced serum PTH levels in calcium- and vitaminD-supplemented mice. These findings corroborate the overall accepted assumption that the positive effects of vitamin D are mainly indirect through its endocrine actions on calcium homeostasis, thus increasing systemic calcium availability. The authors listed in Table 1 share this opinion. However, direct effects of vitamin D locally in the fracture callus could also possibly influence the healing process. Increased VDR expression is found in the fracture callus of supplemented mice, thus supporting this hypothesis (Fischer et al., 2017). VDR expression is described for a broad variety of body's cells, including cells of the immune and skeletal systems (Christakos, 2002; van Driel et al., 2006; van Leeuwen et al., 1991; Wang et al., 2014; Zarei et al., 2016). In vitro experiments demonstrate that $1,25-\mathrm{VitD}_{3}$ binding to the VDR on osteoblasts enhances osteoblast differentiation and mineralisation, as indicated by an increased expression of the osteoblast differentiation marker Alpl (Matsumoto et al., 1991; van Driel et al., 2006; Woeckel et al., 2010). Interestingly, Alpl expression in the fracture callus of mice supplemented with calcium and vitamin $\mathrm{D}$ is also increased. Therefore, enhanced VDR signalling in the fracture callus might contribute to the improved fracture healing observed after calcium and vitamin D supplementation. However, the exact mechanisms need to be determined in the future. For this purpose, also the local expression of $1,25-\mathrm{VitD}_{3}$ target genes and signalling pathways, including genes of vitamin D metabolism itself (e.g. CYP24A1 enzyme for vitamin D degradation) and of bone metabolism (e.g. Rankl, Opg, Wingless signalling), as well as systemic $1,25-$ VitD $_{3}$ levels should be addressed. In addition, other regulatory factors controlling calcium and vitamin D metabolism should be included in any future analysis. Fischer et al. (2017) observe that vitamin D and phosphateregulating FGF23 are increased in mice supplemented with calcium and vitamin D after fracture. In agreement with this, increased FGF23 levels are observed in clinics after successful and uneventful hip-replacement therapy (Goebel et al., 2009). Using a sheep model of regular and delayed fracture healing, Goebel et al. (2009) further observe an up-regulation of the FGF23 mRNA in the fracture callus during regular fracture healing, but not under conditions of delayed healing. By contrast, Fischer et al. (2017) do not detect any differences in the local gene and protein expression of FGF23 and its main receptor FGFR1 in the fracture callus of supplemented mice as compared to control and calcium- and vitaminD-deficient mice. Differences in FGF23 expression patterns might be due to the different animal models used. Therefore, further studies are needed to clarify the observations of systemically increased FGF23 turnover after fracture due to supplementation.

In conclusion, most experimental and clinical studies observe a positive influence of calcium and vitamin D supplementation on the fracture-healing outcome. These findings support the therapeutic potential of calcium and vitamin D supplementation after fracture in clinics for osteoporotic patients with insufficient calcium/vitamin D status. These patients frequently suffer from fracture-healing complications, which might be ameliorated in the case of a sufficient calcium and vitamin D supply.

\section{Post-traumatic bone turnover}

In addition to fracture-healing complications, osteoporotic patients who have experienced their first fragility fracture further display a 2 to 4 -fold increased risk of a future fracture (Ahmed et al., 2013; Center et al., 2007; Kanis et al., 2004; Klotzbuecher et al., 2000; Lyles et al., 2008; Omsland et al., 2013). The fracture risk is higher in the first years after fracture and declines thereafter; however, it always remains higher when compared to patients without a previous fracture (Johnell et al., 2001; Lindsay et al., 2001; Ryg et al., 2009). Subsequent fractures are further related to a reduced mobility and quality of life and an increased mortality in comparison to the first fragility fracture (Bliuc et al., 2009; Sawalha and Parker, 2012). Therefore, therapeutic strategies reducing the secondary fracture risk are needed. However, the reasons for the increased risk of secondary fractures are currently unknown but might be the consequence of an accelerated decline in systemic bone mass in these individuals.

\section{Systemic bone loss following fracture}

Clinical data suggest systemic bone loss following fracture (Table 2a,b). Bone loss occurring at the broken extremity, particularly in close proximity to the fracture area, is well described and mainly 


\begin{tabular}{|c|c|c|c|c|c|c|c|c|c|}
\hline 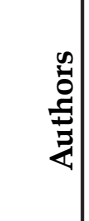 & 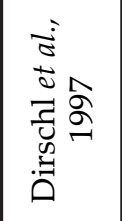 & 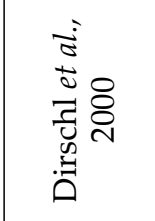 & 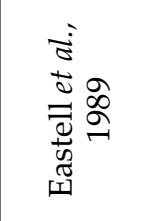 & 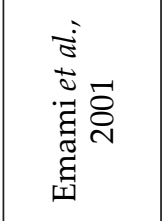 & 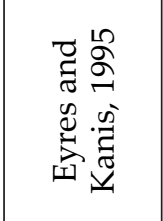 & 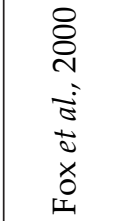 & 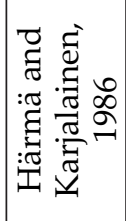 & 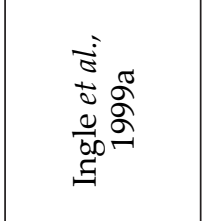 & 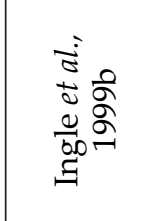 \\
\hline 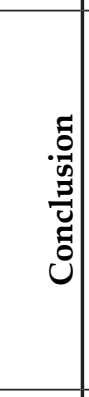 & 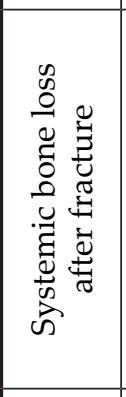 & 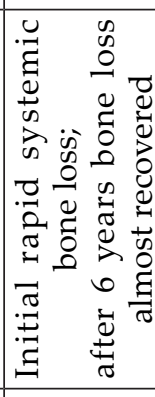 & 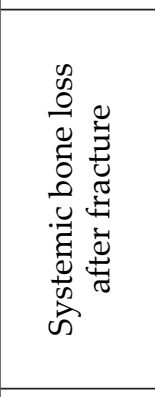 & 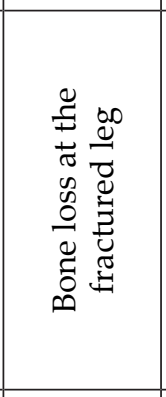 & 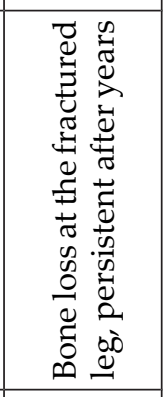 & 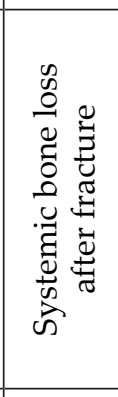 & 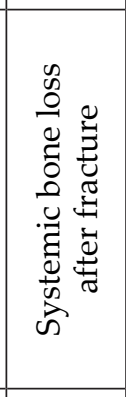 & 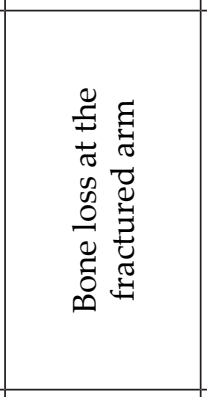 & 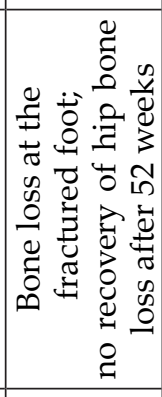 \\
\hline 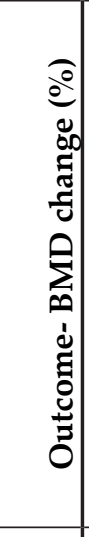 & 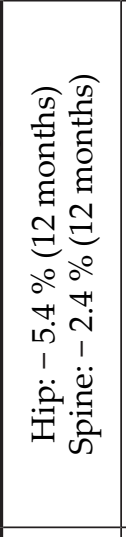 & 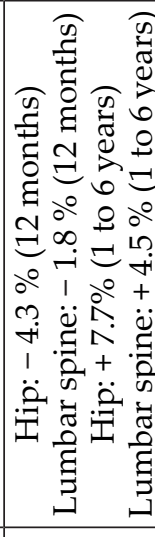 & 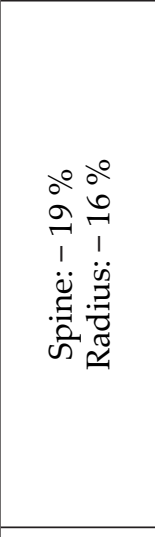 & 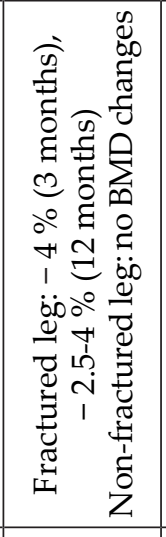 & 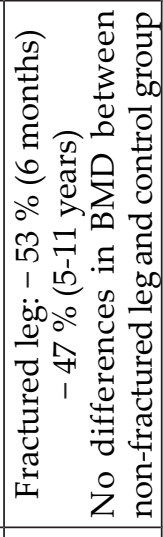 & 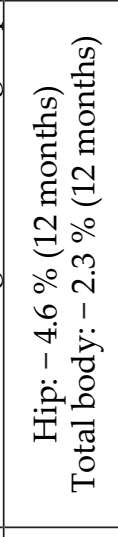 & 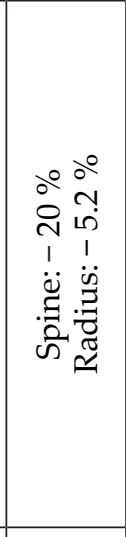 & 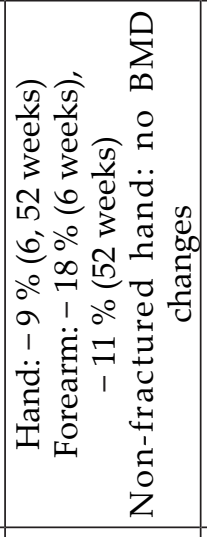 & 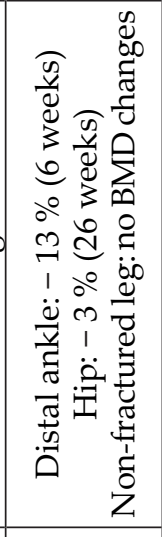 \\
\hline 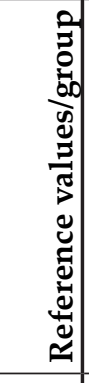 & 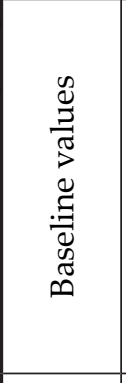 & 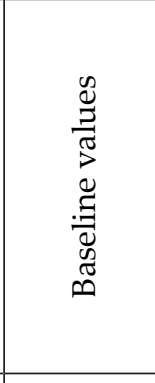 & 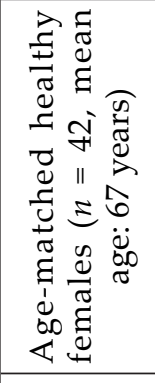 & 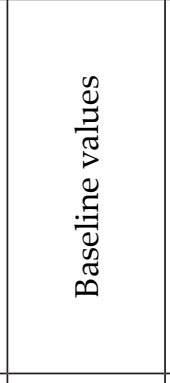 & 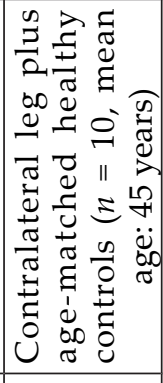 & 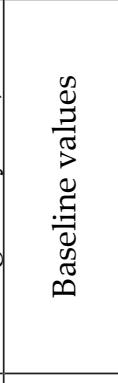 & 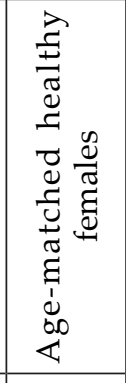 & 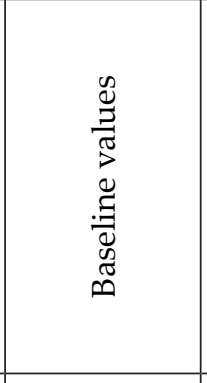 & 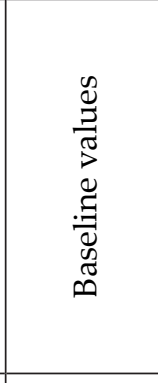 \\
\hline 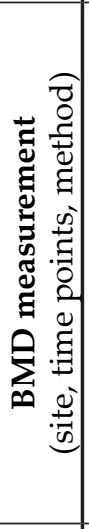 & 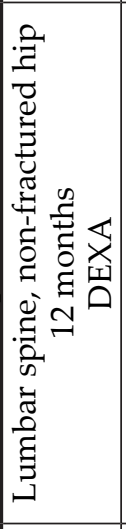 & 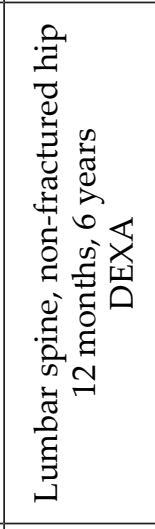 & 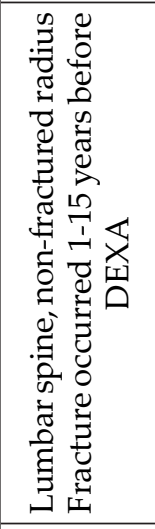 & 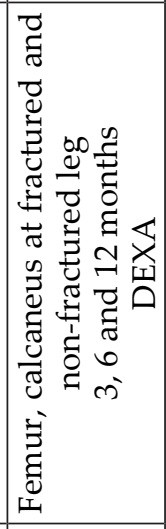 & 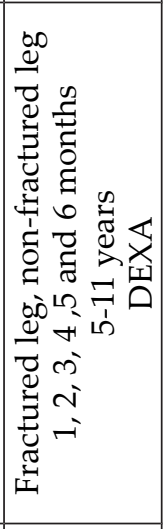 & 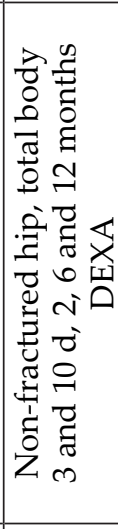 & 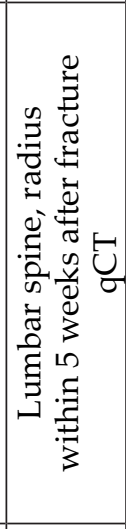 & 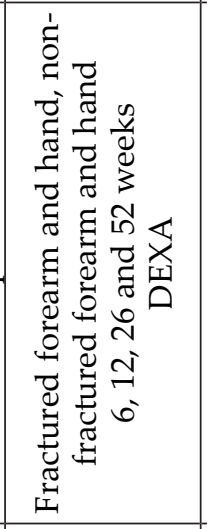 & 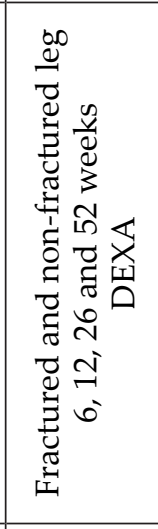 \\
\hline 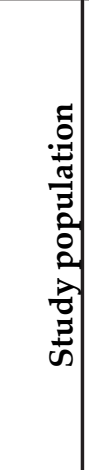 & 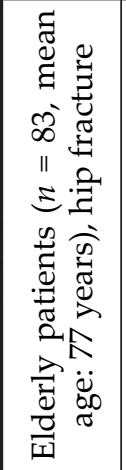 & 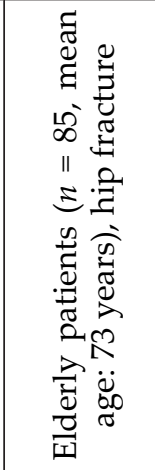 & 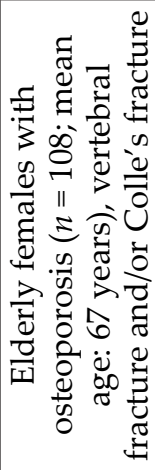 & 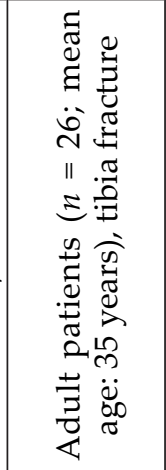 & 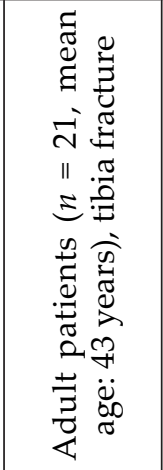 & 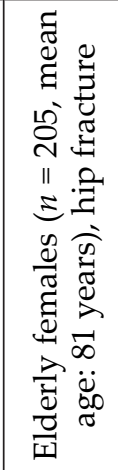 & 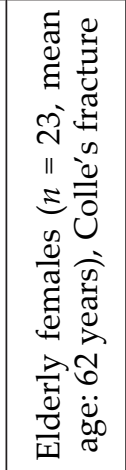 & 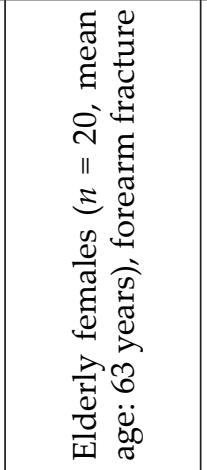 & 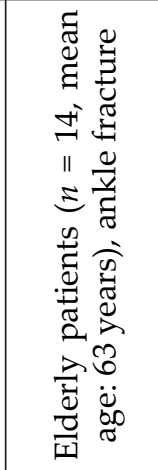 \\
\hline
\end{tabular}




\begin{tabular}{|c|c|c|c|c|c|c|c|c|c|c|c|}
\hline 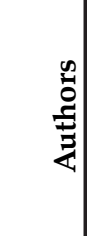 & 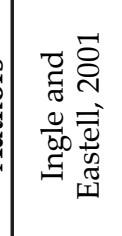 & 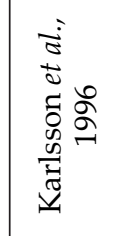 & 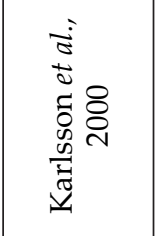 & 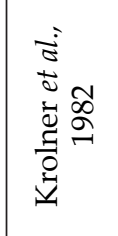 & 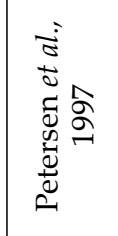 & 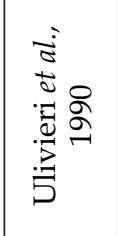 & 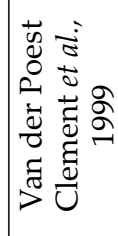 & 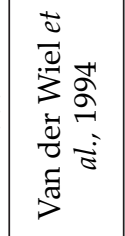 & 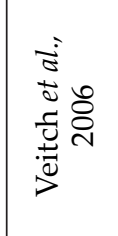 & 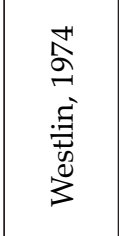 & 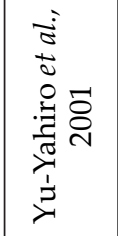 \\
\hline 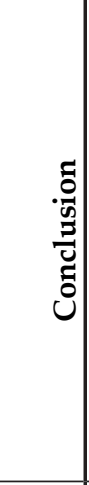 & 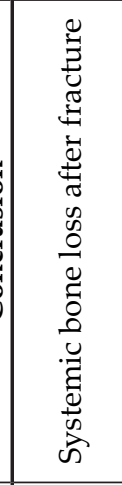 & 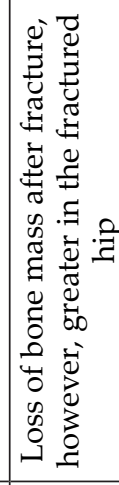 & 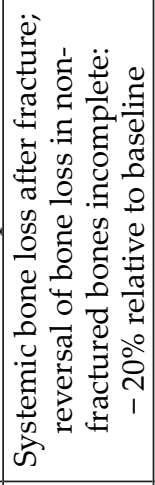 & 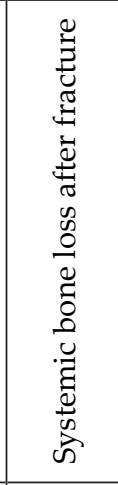 & 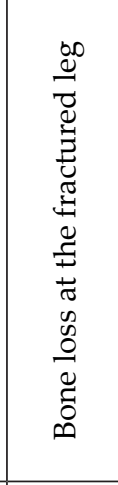 & 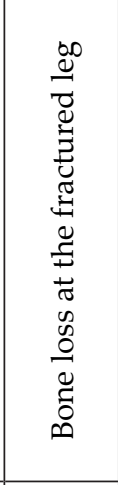 & 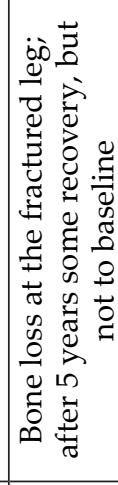 & 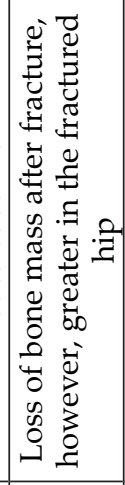 & 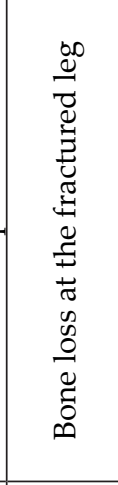 & 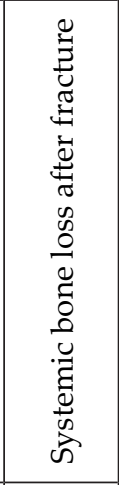 & 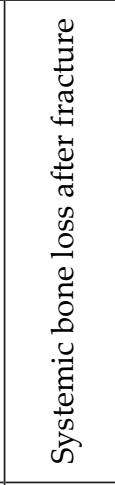 \\
\hline 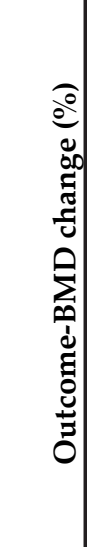 & 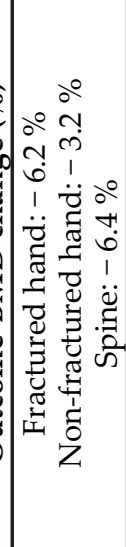 & 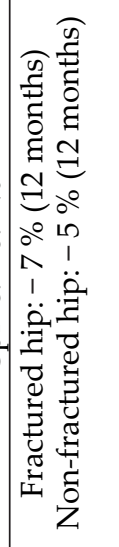 & 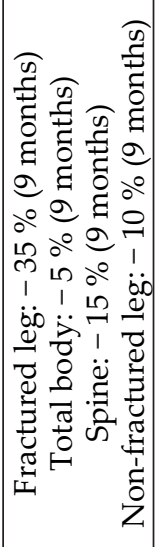 & $\begin{array}{l}\circ \\
a \\
1 \\
\dot{\theta} \\
\text { के }\end{array}$ & 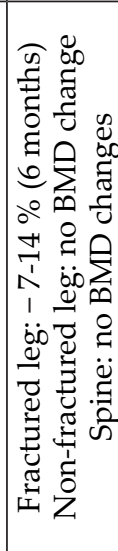 & 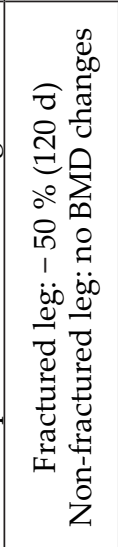 & 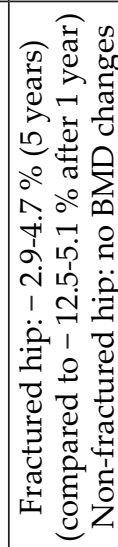 & 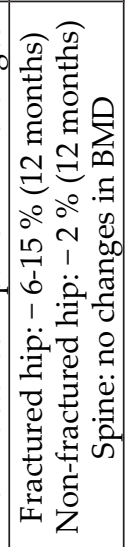 & 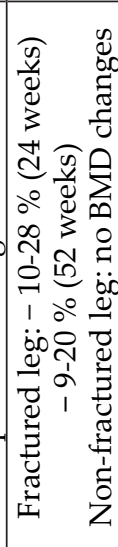 & 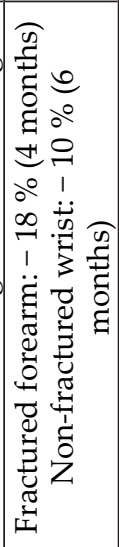 & 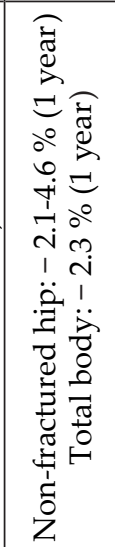 \\
\hline 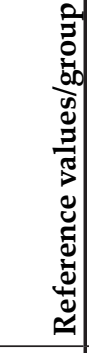 & 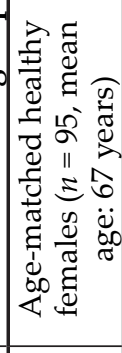 & 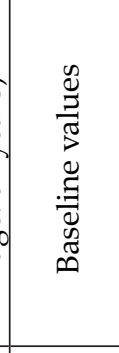 & 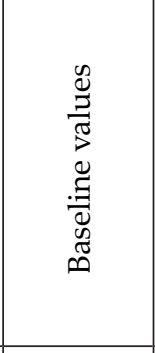 & 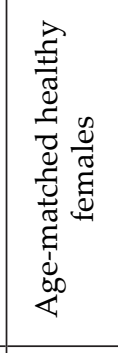 & 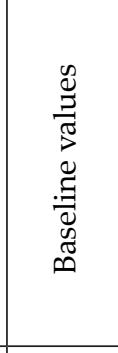 & 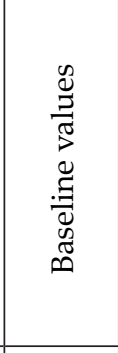 & 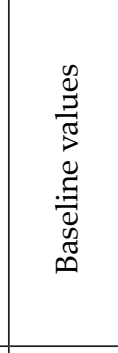 & 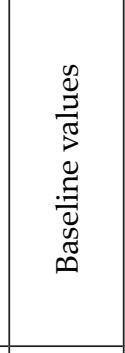 & 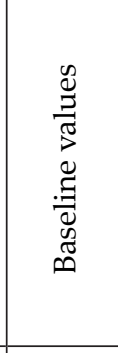 & 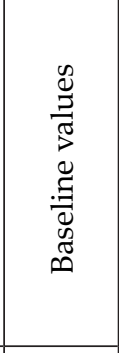 & 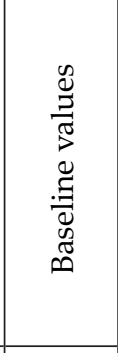 \\
\hline 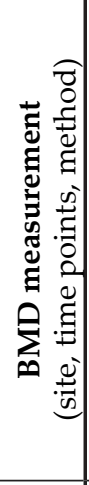 & 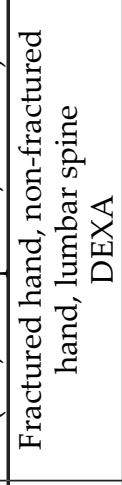 & 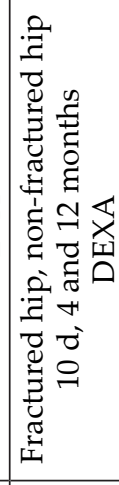 & 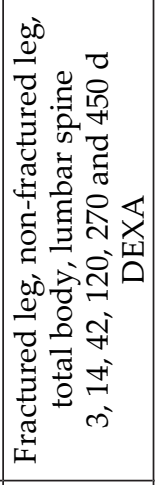 & 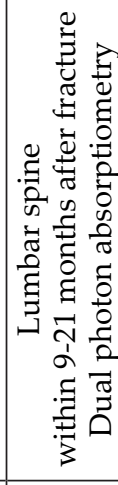 & 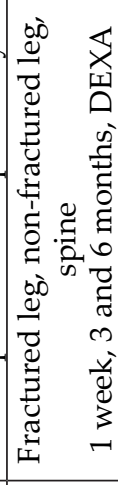 & 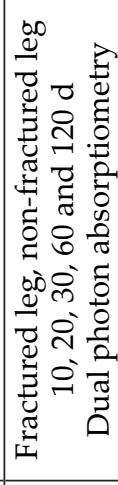 & 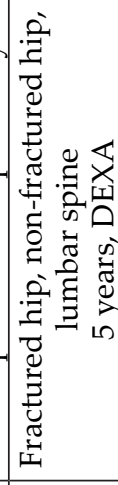 & 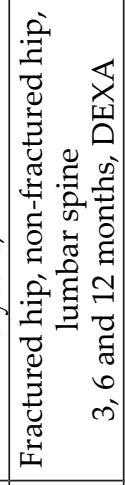 & 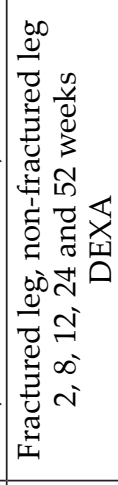 & 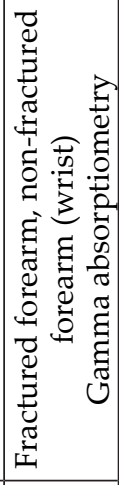 & 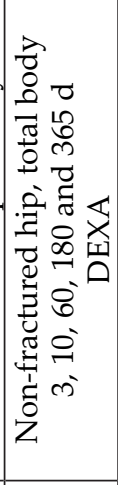 \\
\hline $\begin{array}{l}0 \\
\vdots \\
0 \\
\vec{z} \\
\omega \\
\omega\end{array}$ & 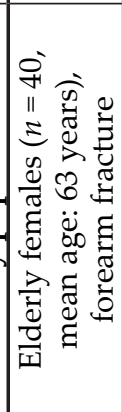 & 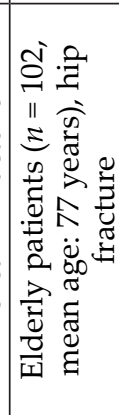 & 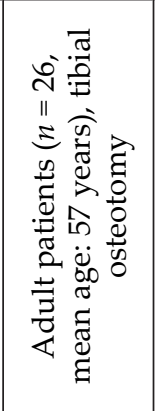 & 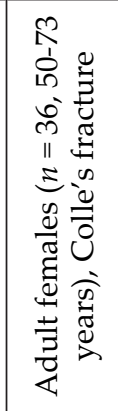 & 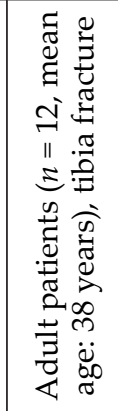 & 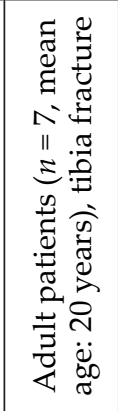 & 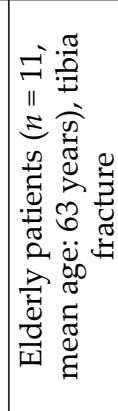 & 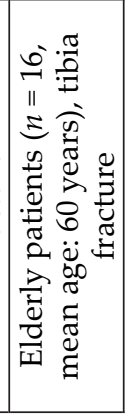 & 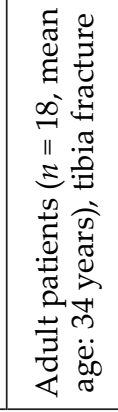 & 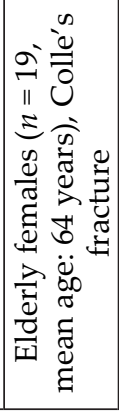 & 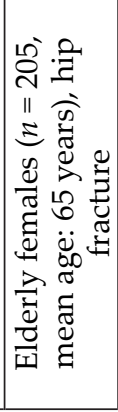 \\
\hline
\end{tabular}


results from disuse because of immobilisation (Karlsson et al., 1996; Van der Wiel et al., 1994). This locally restricted bone mass loss normally recovers after successful bone repair. However, in old and osteoporotic individuals, the deficit in bone mass persists for years, rarely ever achieving pre-fracture mineral levels (Eyres and Kanis, 1995; Ingle et al., 1999a; Karlsson et al., 2000). Furthermore, changes in bone mineral levels are also observed in distal skeletal sites, including the unaffected extremity, spine and whole body of the elderly (Eastell et al., 1989; Härmä and Karjalainen, 1986; Ingle and Eastell, 2001; Krolner et al., 1982; Westlin, 1974). Clinical studies that examine systemic bone loss, including in the non-fractured extremity, spine and whole body, are summarised in Table 2a,b. Highlighting some of these studies, Fox et al. (2000) report that in 205 community-dwelling postmenopausal females displaying a proximal femur fracture, bone loss at the contralateral hip is $4.6 \%$ and in the whole body $2.3 \%$ after 12 months as compared to baseline values. Karlsson et al. (2000) observe a reduction in lumbar spine BMD of up to $15 \%$ after 9 months. Dirschl et al. (1997) detect a mean decline in bone mass of $2.4 \%$ in the lumbar spine and $5.4 \%$ in the contralateral hip 1 year after an osteoporosis-related hip fracture. By contrast, some clinical data exist where no decline in bone mass of the uninjured extremity or the whole body after fracture is reported (Emami et al., 2001; Ingle et al., 1999b; Petersen et al., 1997; Ulivieri et al., 1990; Veitch et al., 2006). However, the studies that do not observe systemic BMD changes after fracture frequently examine a younger fracture cohort, suggesting that post-traumatic bone loss particularly affects the aged population. Moreover, some report total or at least partial recovery of bone mass after 5 or 6 years (Dirschl et al., 2000; van der Poest Clement et al., 1999). Differences may result from variations in the investigated cohorts, including in age, gender, fracture type and treatment. Furthermore, there are considerable differences in the location of the measured bone area and to which values the data were referring to (e.g. to baseline or to an additional control cohort without fracture). Nevertheless, based on most of the clinical data, it is hypothesised that a fracture might induce systemic bone loss, which is particularly enhanced in elderly and osteoporotic patients, thus further reducing bone properties in this risk group.

In 205 postmenopausal females, Yu-Yahiro et al. (2001) observe an association between the reduction in bone mass after hip fracture and an increase in serum PTH levels. PTH levels in these females remain elevated even 1 year after fracture. A rise in serum PTH levels after fracture is also found in other clinical and one experimental study (HaffnerLuntzer et al., 2016; Hitz et al., 2007; Meller et al., 1984). In conclusion, it is hypothesised that a fractureinduced increase in serum PTH levels induces systemic bone loss and may explain the increased risk of subsequent fractures. Possible reasons for post-traumatic bone loss include a reduced calcium supply, immobilisation and an increased inflammatory status after fracture. However, experimental studies that provide the opportunity to study the basic underlying mechanism of a fractureinduced bone loss independent of other influencing factors, including immobilisation, are mostly lacking. The first indications for post-traumatic bone loss are reported by Lane et al. (1984), who show that the calcium-to-phosphorus ratio increases in the skeleton of rats and rabbits after fracture, thus suggesting for the first time a decrease in the amount of calcium in the whole skeleton following a fracture. Using a sheep model, Augat and Claes (2008) confirm increased post-traumatic osteopenia in proximity to the fracture site. Regarding systemic changes in bone mass, Christiansen et al. (2015) observe a loss of trabecular bone mass in the lumbar spine of mice $10 \mathrm{~d}$ after knee injury, which is associated with an avulsion fracture of the distal femur. 2 and 4 weeks after femur fracture, Emami et al. (Age-dependent systemic bone loss and recovery following femoral fracture in mice. In: ORS 2017 Annual Meeting San Diego. Poster Nr. 0714) detect bone loss at distinct sites in middle-aged mice that do not recover bone mass after 6 weeks as compared to young mice. The authors observe increased IL-6 levels at day 3 after fracture in middle-aged mice and hypothesise that the increased inflammatory response after injury may be responsible for systemic bone loss. However, mechanisms inducing increased systemic bone loss need to be further determined.

\section{Role of calcium and vitamin D in post-traumatic bone turnover}

Based on the important function of both calcium and vitamin $\mathrm{D}$ in bone homeostasis, these nutrients may also play a critical role in post-traumatic bone turnover. Supporting this assumption, a significant correlation between the amount of post-traumatic bone loss on one side and insufficient dietary calcium intake and reduced serum vitamin D levels on the other is observed in the clinic (Dirschl et al., 1997). Indeed, Haffner-Luntzer et al. (2016) confirm the involvement of calcium and vitamin D in posttraumatic bone turnover. They demonstrate that mice with intestinal calcium malabsorption, Cckbrdeficient mice (lacking Cckbr, necessary for gastric acidification), display increased serum PTH levels after fracture, which is accompanied by elevated osteoclastic bone resorption in the non-fractured skeleton. Notably, fracture healing is unaffected in Cckbr-deficient mice (Haffner-Luntzer et al., 2016). These results indicate for the first time that under conditions of insufficient dietary calcium supply, the calcium needed for callus mineralisation is increasingly mobilised from distal skeletal sites in favour of successful bone repair.

Confirming the previous results obtained in mice with intestinal calcium malabsorption, Fischer et al. (2017) demonstrate that calcium- and vitamin-D- 
Gl tract

a

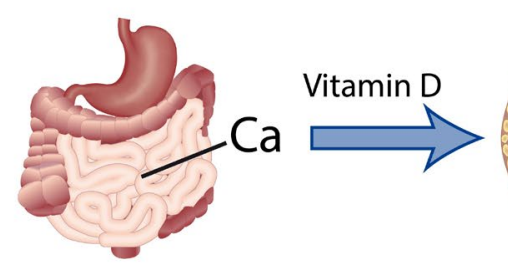

b
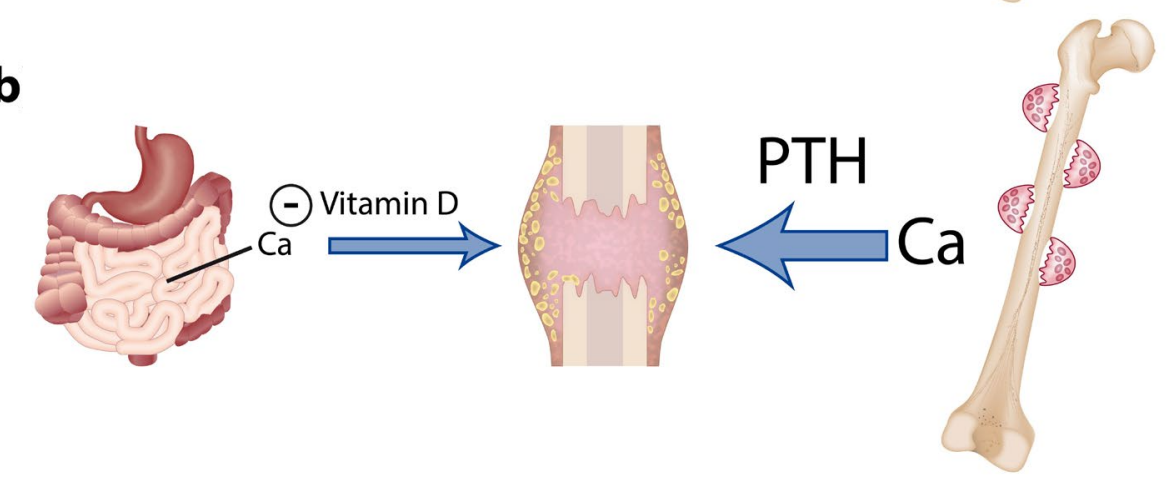

C

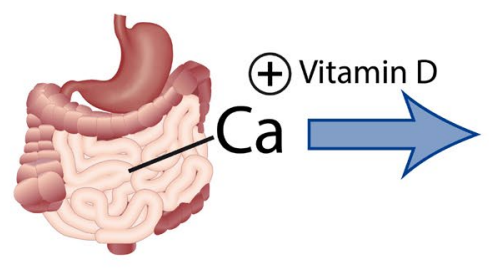

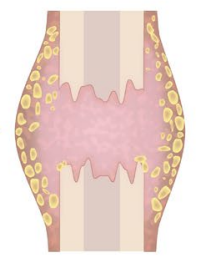

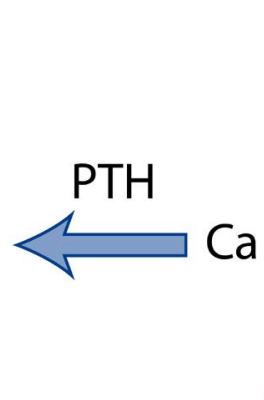

Fracture callus
Skeleton
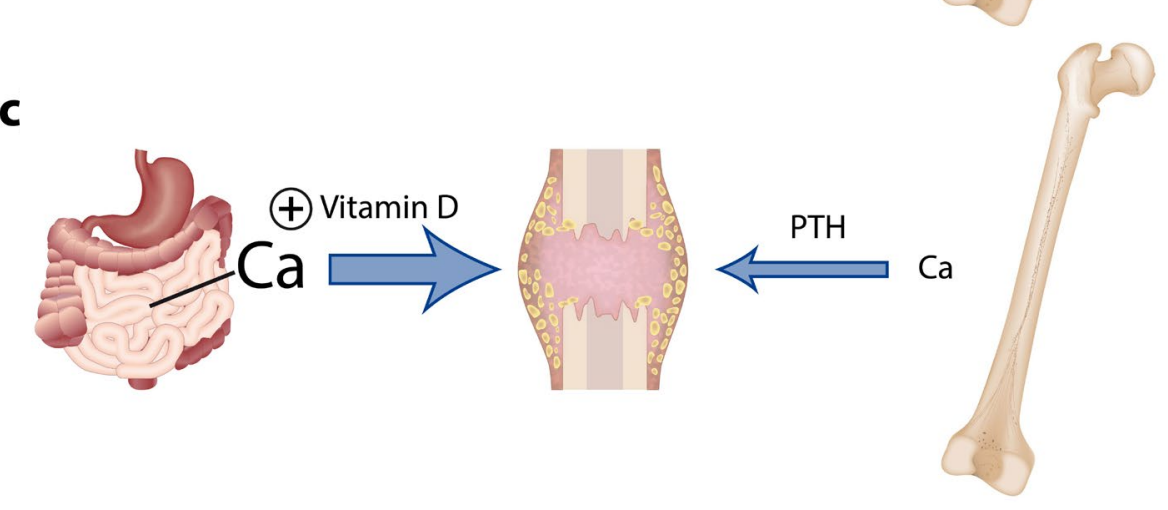

Fig. 2. Model of the impact of calcium and vitamin D on post-traumatic bone turnover. (a) Healthy state of normal calcium supply and vitamin D status satisfactory for successful fracture healing and skeletal health. (b) Insufficient calcium supply and reduced vitamin D stimulate PTH-induced osteoclastic bone resorption in the non-fractured skeleton to guarantee calcium needs for fracture-callus mineralisation, however, further worsening skeletal health. (c) Increased calcium supply and sufficient vitamin D provide calcium needs for fracture healing without increasing calcium mobilisation from non-fractured skeletal sites. $\mathrm{Ca}=$ calcium.

deficient mice similarly display a rise in PTH serum levels after fracture and that fracture healing is only marginally disturbed in these mice. In addition, fractured calcium- and vitamin D-deficient mice exhibit significantly more osteoclasts in their lumbar vertebrae relative to non-fractured deficient mice, indicating enhanced osteoclastic bone resorption in the remote skeleton after fracture. In addition, increased osteoclastic bone resorption in fractured deficient mice result in bone loss (Fischer et al., 2017). These results indicate that when a fracture occurs under calcium- and vitamin-D-deficient conditions, the increasing need for calcium stimulates an increase in serum PTH levels to induce osteoclastic bone resorption at distal skeletal sites. Because of the increased calcium mobilisation, sufficient amounts of calcium can be provided for fracture callus mineralisation. The increased post-traumatic calcium mobilisation might be the reason why bone repair is not or only marginally disturbed under calcium and vitamin D deficiency, however, at the clear expense of bone properties (Fig. 2). It might also explain the results of most of the other experimental studies, which do not observe a delay in fracture healing under calcium- and vitamin-D-deficient conditions. The enhanced post-traumatic calcium mobilisation might explain the dramatically increased risk of secondary fractures. 
Importantly, Fischer et al. (2017) observe no increase in PTH serum levels and osteoclastic bone resorption when deficient mice are supplemented with calcium and vitamin $\mathrm{D}$ directly after fracture. Furthermore, they do not observe a decline in bone properties at distal skeletal sites because of calcium and vitamin D treatment. Additionally, in mice displaying intestinal calcium malabsorption, calcium supplementation reduce secondary hyperparathyroidism and bone resorption in the non-fractured skeleton (HaffnerLuntzer et al., 2016). Confirming these results, the only experimental study that investigate the effect of vitamin $\mathrm{D}$ on post-traumatic bone turnover observe that $1,25-\mathrm{VitD}_{3}$ injections in rats reduce post-fracture osteopenia (Lindgren et al., 1981). Supporting the experimental findings, calcium and vitamin D supplementation after fracture can increase lumbar BMD in elderly patients with hip fracture when compared to patients of the placebo group, where lumbar BMD decrease and PTH levels increase (Hitz et al., 2007).

Concluding, these findings clearly indicate the need for calcium and vitamin D supplementation during fracture healing in patients with calcium and vitamin D deficiency or osteoporosis to prevent systemic bone loss following fracture and to reduce the risk of secondary fractures. In addition, multipleinjured patients, who display many fractures and thus require larger amounts of calcium for the mineralisation of numerous fracture calli, might benefit from calcium and vitamin D supplementation during fracture healing.

\section{Summary and future directions}

This review summarises the current literature on how calcium and vitamin D influence fracture healing and post-traumatic bone turnover. Data reviewed here demonstrate that the role of calcium and vitamin D in fracture healing is still poorly investigated and existing results are inconsistent. However, there is increasing evidence that calcium and vitamin $\mathrm{D}$ deficiency enhances systemic bone loss after fracture, because the calcium necessary for fracture callus mineralisation is increasingly mobilised from the remote skeleton in favour of fracture healing when the calcium and vitamin D status is insufficient. This increased post-traumatic bone loss might exacerbate osteoporosis and explain the 3-fold increased risk of secondary fractures in the clinic. Importantly, experimental data show that calcium and vitamin D supplementation, initiated after fracture and continued during the entire healing process, prevents post-traumatic bone loss. In addition, several experimental studies observe an improvement in bone regeneration because of calcium and vitamin $D$ supplementation. These findings imply a high clinical potential of calcium and vitamin D supplementation on fracture-healing outcome and post-traumatic bone turnover. However, there is a paucity of clinical research that has investigated the effects of calcium and vitamin $\mathrm{D}$ on fracture healing or post-traumatic bone turnover. More clinical studies should be performed in which calcium and vitamin D are supplemented during the fracture-healing process of patients displaying osteoporosis, calcium and vitamin $\mathrm{D}$ deficiency or multiple fractures.

\section{Acknowledgments}

This work was supported by a grant from the German Research Foundation (Collaborative Research Centre CRC1149 to A. Ignatius).

\section{References}

Ahmed LA, Center JR, Bjornerem A, Bluic D, Joakimsen RM, Jorgensen L, Meyer HE, Nguyen ND, Nguyen TV, Omsland TK, Stormer J, Tell GS, van Geel TA, Eisman JA, Emaus N (2013) Progressively increasing fracture risk with advancing age after initial incident fragility fracture: the Tromso study. J Bone Miner Res 28: 2214-2221.

Amling M, Priemel M, Holzmann T, Chapin K, Rueger JM, Baron R, Demay MB (1999) Rescue of the skeletal phenotype of vitamin $D$ receptor-ablated mice in the setting of normal mineral ion homeostasis: formal histomorphometric and biomechanical analyses. Endocrinology 140: 4982-4987.

Aslan B, Kalaci A, Bozlar M, Atik E, Yanat AN, Tasci A (2006) Effects of vitamin D3 and calcium on fracture healing in rats. Turkiye Klinikleri J Med Sci 26: 507-513.

Augat P, Claes L (2008) Increased cortical remodeling after osteotomy causes posttraumatic osteopenia. Bone 43: 539-543.

Baldan A, Giusti A, Bosi C, Malaventura C, Musso M, Forni GL, Volpato S, Zuliani G, Borgna-Pignatti C (2015) Klotho, a new marker for osteoporosis and muscle strength in beta-thalassemia major. Blood Cells Mol Dis 55: 396-401.

Bauer GC (1954) Rate of bone salt formation in a healing fracture determined in rats by means of radiocalcium. Acta Orthop Scand 23: 169-191.

Beil FT, Barvencik F, Gebauer M, Seitz S, Rueger JM, Ignatius A, Pogoda P, Schinke T, Amling M (2010) Effects of estrogen on fracture healing in mice. J Trauma 69: 1259-1265.

Bellantonio S, Fortinsky R, Prestwood K (2001) How well are community-living women treated for osteoporosis after hip fracture? J Am Geriatr Soc 49: 1197-1204.

Ben-Dov IZ, Galitzer H, Lavi-Moshayoff V, Goetz R, Kuro-o M, Mohammadi M, Sirkis R, Naveh-Many T, Silver J (2007) The parathyroid is a target organ for FGF23 in rats. J Clin Invest 117: 4003-4008. 
Bischoff-Ferrari HA, Orav EJ, Willett WC, Dawson-Hughes B (2014) The effect of vitamin D supplementation on skeletal, vascular, or cancer outcomes. Lancet Diabetes Endocrinol 2: 363-364.

Bischoff-Ferrari HA, Rees JR, Grau MV, Barry E, Gui J, Baron JA (2008) Effect of calcium supplementation on fracture risk: a double-blind randomized controlled trial. Am J Clin Nutr 87: 19451951.

Bischoff-Ferrari HA, Willett WC, Wong JB, Giovannucci E, Dietrich T, Dawson-Hughes B (2005) Fracture prevention with vitamin $\mathrm{D}$ supplementation: a meta-analysis of randomized controlled trials. JAMA 293: 2257-2264.

Bliuc D, Nguyen ND, Milch VE, Nguyen TV, Eisman JA, Center JR (2009) Mortality risk associated with low-trauma osteoporotic fracture and subsequent fracture in men and women. JAMA 301: 513-521.

Bolland MJ, Leung W, Tai V, Bastin S, Gamble GD, Grey A, Reid IR (2015) Calcium intake and risk of fracture: systematic review. BMJ 351: DOI: 10.1136/ bmj.h4580.

Brown J, Ignatius A, Amling M, Barvencik F (2013a) New perspectives on vitamin D sources in Germany based on a novel mathematical bottom-up model of $25(\mathrm{OH}) \mathrm{D}$ serum concentrations. Eur J Nutr 52: 1733-1742.

Brown J, Sandmann A, Ignatius A, Amling M, Barvencik F (2013b) New perspectives on vitamin D food fortification based on a modeling of $25(\mathrm{OH}) \mathrm{D}$ concentrations. Nutr J 12: DOI: 10.1186/1475-2891-12151.

Bruyere O, Slomian J, Beaudart C, Buckinx F, Cavalier E, Gillain S, Petermans J, Reginster JY (2014) Prevalence of vitamin D inadequacy in European women aged over 80 years. Arch Gerontol Geriatr 59: 78-82.

Center JR, Bliuc D, Nguyen TV, Eisman JA (2007) Risk of subsequent fracture after low-trauma fracture in men and women. JAMA 297: 387-394.

Chalhoub D, Marques E, Meirelles O, Semba RD, Ferrucci L, Satterfield S, Nevitt M, Cauley JA, Harris T, Health ABCS (2016) Association of serum Klotho with loss of bone mineral density and fracture risk in older adults. J Am Geriatr Soc 64: e304-e308.

Chapuy MC, Arlot ME, Duboeuf F, Brun J, Crouzet B, Arnaud S, Delmas PD, Meunier PJ (1992) Vitamin D3 and calcium to prevent hip fractures in the elderly women. N Engl J Med 327: 1637-1642.

Christakos S (2002)Vitamin D gene regulation. In: Principles of bone biology.Bilezikian JP, Raisz LG and Rodan GA, edition. Academic Press, pp 573-586.

Christakos S, Dhawan P, Verstuyf A, Verlinden L, Carmeliet G (2016) Vitamin D: metabolism, molecular mechanism of action, and pleiotropic effects. Physiol Rev 96: 365-408.

Christakos S, Lieben L, Masuyama R, Carmeliet G (2014) Vitamin D endocrine system and the intestine. Bonekey Rep 3: DOI: 10.1038/bonekey.2013.230.
Christiansen BA, Emami AJ, Fyhrie DP, Satkunananthan PB, Hardisty MR (2015) Trabecular bone loss at a distant skeletal site following noninvasive knee injury in mice. J Biomech Eng 137: DOI: 10.1115/1.4028824.

Claes L, Recknagel S, Ignatius A (2012) Fracture healing under healthy and inflammatory conditions. Nat Rev Rheumatol 8: 133-143.

Consensus Development Conference (1997) Who are candidates for prevention and treatment for osteoporosis? Osteoporos Int 7: 1-6.

Cooley H, Jones G (2001) A population-based study of fracture incidence in southern Tasmania: lifetime fracture risk and evidence for geographic variations within the same country. Osteoporos Int 12: $124-130$.

Cornell CN, Lane JM, Poynton AR (2003) Orthopedic management of vertebral and long bone fractures in patients with osteoporosis. Clin Geriatr Med 19: 433-455.

Cosman F, de Beur SJ, LeBoff MS, Lewiecki EM, Tanner B, Randall S, Lindsay R, National Osteoporosis F (2014) Clinician's guide to prevention and treatment of osteoporosis. Osteoporos Int 25: 2359-2381.

Crockett JC, Rogers MJ, Coxon FP, Hocking LJ, Helfrich MH (2011) Bone remodelling at a glance. J Cell Sci 124: 991-998.

Delgado-Martinez AD, Martinez ME, Carrascal MT, Rodriguez-Avial M, Munuera L (1998) Effect of 25-OH-vitamin D on fracture healing in elderly rats. J Orthop Res 16: 650-653.

Di Monaco M, Vallero F, Di Monaco R, Tappero R, Cavanna A (2006) 25-hydroxyvitamin D, parathyroid hormone, and functional recovery after hip fracture in elderly patients. J Bone Miner Metab 24: 42-47.

Dirschl DR, Henderson RC, Oakley WC (1997) Accelerated bone mineral loss following a hip fracture: a prospective longitudinal study. Bone 21: 79-82.

Dirschl DR, Piedrahita L, Henderson RC (2000) Bone mineral density 6 years after a hip fracture: a prospective, longitudinal study. Bone 26: 95-98.

Doepfner W (1970) Consequences of calcium andor phosphorus deficient diets on various parameters of callus formation and on growth rate in young rats. Br J Pharmacol 39: 188P-189P.

Doetsch AM, Faber J, Lynnerup N, Watjen I, Bliddal H, Danneskiold-Samsoe B (2004) The effect of calcium and vitamin D3 supplementation on the healing of the proximal humerus fracture: a randomized placebo-controlled study. Calcif Tissue Int 75: 183-188.

Eastell R, Wahner HW, O'Fallon WM, Amadio PC, Melton LJ, 3rd, Riggs BL (1989) Unequal decrease in bone density of lumbar spine and ultradistal radius in Colles' and vertebral fracture syndromes. J Clin Invest 83: 168-174.

Einhorn TA, Bonnarens F, Burstein AH (1986) The contributions of dietary protein and mineral to the healing of experimental fractures. A biomechanical study. J Bone Joint Surg Am 68: 1389-1395. 
Einhorn TA, Gerstenfeld LC (2015) Fracture healing: mechanisms and interventions. Nat Rev Rheumatol 11: 45-54.

Emami A, Larsson S, Hellquist E, Mallmin H (2001) Limited bone loss in the hip and heel after reamed intramedullary fixation and early weightbearing of tibial fractures. J Orthop Trauma 15: 560 565.

Eschle D, Aeschlimann AG (2011) Is supplementation of vitamin d beneficial for fracture healing? A short review of the literature. Geriatr Orthop Surg Rehabil 2: 90-93.

European Food Safety Authority SCoF, Scientific Panel on Dietetic Products, Nutrition and Allergies (2006) Tolerable upper intake levels for vitamins and minerals. The EFSA Journal.

Eyres KS, Kanis JA (1995) Bone loss after tibial fracture. Evaluated by dual-energy X-ray absorptiometry. J Bone Joint Surg Br 77: 473-478.

Fischer V, Haffner-Luntzer M, Prystaz K, Scheidt AV, Busse B, Schinke T, Amling M, Ignatius A (2017) Calcium and vitamin-D deficiency marginally impairs fracture healing but aggravates posttraumatic bone loss in osteoporotic mice. Sci Rep 7: DOI: 10.1038/s41598-017-07511-2.

Fleet JC (2017) The role of vitamin D in the endocrinology controlling calcium homeostasis. Mol Cell Endocrinol 453: 36-45.

Follin SL, Black JN, McDermott MT (2003) Lack of diagnosis and treatment of osteoporosis in men and women after hip fracture. Pharmacotherapy 23: 190-198.

Fox KM, Magaziner J, Hawkes WG, Yu-Yahiro J, Hebel JR, Zimmerman SI, Holder L, Michael R (2000) Loss of bone density and lean body mass after hip fracture. Osteoporos Int 11: 31-35.

Fu L, Tang T, Miao Y, Hao Y, Dai K (2009) Effect of 1,25-dihydroxy vitamin D3 on fracture healing and bone remodeling in ovariectomized rat femora. Bone 44: 893-898.

Gennari C (2001) Calcium and vitamin D nutrition and bone disease of the elderly. Public Health Nutr 4: 547-559.

German Nutrition Society (2012) New reference values for vitamin D. Ann Nutr Metab 60: 241-246.

German Nutrition Society (2013) New reference values for calcium. Ann Nutr Metab 63: 186-192.

Goebel S, Lienau J, Rammoser U, Seefried L, Wintgens KF, Seufert J, Duda G, Jakob F, Ebert R (2009) FGF23 is a putative marker for bone healing and regeneration. J Orthop Res 27: 1141-1146.

Gonzalez-Gross M, Valtuena J, Breidenassel C, Moreno LA, Ferrari M, Kersting M, De Henauw S, Gottrand F, Azzini E, Widhalm K, Kafatos A, Manios Y, Stehle P, Group HS (2012) Vitamin D status among adolescents in Europe: the healthy lifestyle in Europe by nutrition in adolescence study. Br J Nutr 107: 755764.

Gorter EA, Hamdy NA, Appelman-Dijkstra NM, Schipper IB (2014) The role of vitamin D in human fracture healing: a systematic review of the literature. Bone 64: 288-297.

Haffner-Luntzer M, Fischer V, Prystaz K, Liedert A, Ignatius A (2017) The inflammatory phase of fracture healing is influenced by oestrogen status in mice. Eur J Med Res 22: DOI: 10.1186/s40001-0170264-y.

Haffner-Luntzer M, Heilmann A, Heidler V, Liedert A, Schinke T, Amling M, Yorgan TA, Vom Scheidt A, Ignatius A (2016) Hypochlorhydriainduced calcium malabsorption does not affect fracture healing but increases post-traumatic bone loss in the intact skeleton. J Orthop Res 34: 1914-1921.

Haffner-Luntzer M, Kovtun A, Lackner I, Modinger Y, Hacker S, Liedert A, Tuckermann J, Ignatius A (2018) Estrogen receptor alpha- (ERalpha), but not ERbeta-signaling, is crucially involved in mechanostimulation of bone fracture healing by whole-body vibration. Bone 110: 11-20.

Härmä M, Karjalainen P (1986) Trabecular osteopenia in Colles' fracture. Acta Orthop Scand 57: 38-40.

Harvey NC, Biver E, Kaufman JM, Bauer J, Branco J, Brandi ML, Bruyere O, Coxam V, CruzJentoft A, Czerwinski E, Dimai H, Fardellone P, Landi F, Reginster JY, Dawson-Hughes B, Kanis JA, Rizzoli R, Cooper C (2017) The role of calcium supplementation in healthy musculoskeletal ageing: an expert consensus meeting of the European Society for Clinical and Economic Aspects of Osteoporosis, Osteoarthritis and Musculoskeletal Diseases (ESCEO) and the International Foundation for Osteoporosis (IOF). Osteoporos Int 28: 447-462.

Harwood RH, Sahota O, Gaynor K, Masud T, Hosking DJ, Nottingham Neck of Femur S (2004) A randomised, controlled comparison of different calcium and vitamin D supplementation regimens in elderly women after hip fracture: the Nottingham Neck of Femur (NONOF) study. Age Ageing 33: 4551.

Heilmann A, Schinke T, Bindl R, Wehner T, Rapp A, Haffner-Luntzer M, Nemitz C, Liedert A, Amling M, Ignatius A (2013) The Wnt serpentine receptor Frizzled-9 regulates new bone formation in fracture healing. PLoS One 8: DOI: 10.1371/journal. pone.0084232.

Herman H, Richelle L (1961) [Exchangeable calcium of the mineral substance of bone studied with the aid of Ca45. VII. Comparative activity of the fractions of total bone with different densities]. Bull Soc Chim Biol (Paris) 43: 273-282.

Hernlund E, Svedbom A, Ivergard M, Compston J, Cooper C, Stenmark J, McCloskey EV, Jonsson B, Kanis JA (2013) Osteoporosis in the European Union: medical management, epidemiology and economic burden. A report prepared in collaboration with the International Osteoporosis Foundation (IOF) and the European Federation of Pharmaceutical Industry Associations (EFPIA). Arch Osteoporos 8: 136. DOI: 10.1007/s11657-013-0136-1. 
Hintzpeter B, Mensink GB, Thierfelder W, Muller MJ, Scheidt-Nave C (2008a) Vitamin D status and health correlates among German adults. Eur J Clin Nutr 62: 1079-1089.

Hintzpeter B, Scheidt-Nave C, Muller MJ, Schenk L, Mensink GB (2008b) Higher prevalence of vitamin $\mathrm{D}$ deficiency is associated with immigrant background among children and adolescents in Germany. J Nutr 138: 1482-1490.

Hitz MF, Jensen JE, Eskildsen PC (2007) Bone mineral density and bone markers in patients with a recent low-energy fracture: effect of 1 y of treatment with calcium and vitamin D. Am J Clin Nutr 86: 251259.

Holick MF, Binkley NC, Bischoff-Ferrari HA, Gordon CM, Hanley DA, Heaney RP, Murad $\mathrm{MH}$, Weaver CM, Endocrine S (2011) Evaluation, treatment, and prevention of vitamin D deficiency: an Endocrine Society clinical practice guideline. J Clin Endocrinol Metab 96: 1911-1930.

Holick MF, Chen TC (2008) Vitamin D deficiency: a worldwide problem with health consequences. Am J Clin Nutr 87: 1080S-1086S.

Holick MF, Uskokovic M, Henley JW, MacLaughlin J, Holick SA, Potts JT, Jr. (1980) The photoproduction of 1 alpha,25-dihydroxyvitamin D3 in skin: an approach to the therapy of vitamin-D-resistant syndromes. N Engl J Med 303: 349-354.

Hossein-nezhad A, Holick MF (2013) Vitamin D for health: a global perspective. Mayo Clin Proc 88: 720-755.

Hsu H, Lacey DL, Dunstan CR, Solovyev I, Colombero A, Timms E, Tan HL, Elliott G, Kelley MJ, Sarosi I, Wang L, Xia XZ, Elliott R, Chiu L, Black T, Scully S, Capparelli C, Morony S, Shimamoto G, Bass MB, Boyle WJ (1999) Tumor necrosis factor receptor family member RANK mediates osteoclast differentiation and activation induced by osteoprotegerin ligand. Proc Natl Acad Sci U S A 96: 3540-3545.

Ingle BM, Eastell R (2001) Bone loss from the hand in women following distal forearm fracture. Osteoporos Int 12: 610-615.

Ingle BM, Hay SM, Bottjer HM, Eastell R (1999a) Changes in bone mass and bone turnover following ankle fracture. Osteoporos Int 10: 408-415.

Ingle BM, Hay SM, Bottjer HM, Eastell R (1999b) Changes in bone mass and bone turnover following distal forearm fracture. Osteoporos Int 10: 399-407.

Institute of Medicine (2011) Dietary reference intakes for calcium and vitamin D. The National Academies Press (US), Washington (DC).

Ireland P, Fordtran JS (1973) Effect of dietary calcium and age on jejunal calcium absorption in humans studied by intestinal perfusion. J Clin Invest 52: 2672-2681.

Islam AA, Rasubala L, Yoshikawa H, Shiratsuchi Y, Ohishi M (2005) Healing of fractures in osteoporotic rat mandible shown by the expression of bone morphogenetic protein-2 and tumour necrosis factoralpha. Br J Oral Maxillofac Surg 43: 383-391.
Johnell O, Kanis JA (2006) An estimate of the worldwide prevalence and disability associated with osteoporotic fractures. Osteoporos Int 17: 1726-1733.

Johnell O, Oden A, Caulin F, Kanis JA (2001) Acute and long-term increase in fracture risk after hospitalization for vertebral fracture. Osteoporos Int 12: 207-214.

Kanis JA (2007) WHO scientific group on assessment of osteoporosis at the primary health-care level. University of Sheffield, Sheffield, UK.

Kanis JA, Johnell O, De Laet C, Johansson $\mathrm{H}$, Oden A, Delmas P, Eisman J, Fujiwara S, Garnero P, Kroger H, McCloskey EV, Mellstrom D, Melton LJ, Pols H, Reeve J, Silman A, Tenenhouse A (2004) A meta-analysis of previous fracture and subsequent fracture risk. Bone 35: 375-382.

Kanis JA, Johnell O, Oden A, Jonsson B, De Laet C, Dawson A (2000) Risk of hip fracture according to the World Health Organization criteria for osteopenia and osteoporosis. Bone 27: 585-590.

Karlsson M, Nilsson JA, Sernbo I, Redlund-Johnell I, Johnell O, Obrant KJ (1996) Changes of bone mineral mass and soft tissue composition after hip fracture. Bone 18: 19-22.

Karlsson MK, Josefsson PO, Nordkvist A, Akesson K, Seeman E, Obrant KJ (2000) Bone loss following tibial osteotomy: a model for evaluating posttraumatic osteopenia. Osteoporos Int 11: 261-264.

Ke HZ, Richards WG, Li X, Ominsky MS (2012) Sclerostin and Dickkopf-1 as therapeutic targets in bone diseases. Endocr Rev 33: 747-783.

Klotzbuecher CM, Ross PD, Landsman PB, Abbott TA, 3rd, Berger M (2000) Patients with prior fractures have an increased risk of future fractures: a summary of the literature and statistical synthesis. J Bone Miner Res 15: 721-739.

Kolb JP, Schilling AF, Bischoff J, Novo de Oliveira A, Spiro A, Hoffmann M, Amling M, Rueger JM, Lehmann W (2013) Calcium homeostasis influences radiological fracture healing in postmenopausal women. Arch Orthop Trauma Surg 133: 187-192.

Krause M, Keller J, Beil B, van Driel I, Zustin J, Barvencik F, Schinke T, Amling M (2015) Calcium gluconate supplementation is effective to balance calcium homeostasis in patients with gastrectomy. Osteoporos Int 26: 987-995.

Krolner B, Tondevold E, Toft B, Berthelsen B, Nielsen SP (1982) Bone mass of the axial and the appendicular skeleton in women with Colles' fracture: its relation to physical activity. Clin Physiol 2: 147-157.

Kuchuk NO, van Schoor NM, Pluijm SM, Chines A, Lips P (2009) Vitamin D status, parathyroid function, bone turnover, and BMD in postmenopausal women with osteoporosis: global perspective. J Bone Miner Res 24: 693-701.

Kuro-o M, Matsumura Y, Aizawa H, Kawaguchi H, Suga T, Utsugi T, Ohyama Y, Kurabayashi M, Kaname T, Kume E, Iwasaki H, Iida A, Shiraki-Iida T, Nishikawa S, Nagai R, Nabeshima YI (1997) Mutation 
of the mouse klotho gene leads to a syndrome resembling ageing. Nature 390: 45-51.

Lane JM, Betts F, Posner AS, Yue DW (1984) Mineral parameters in early fracture repair. J Bone Joint Surg Am 66: 1289-1293.

Lehmann G, Pfeil A, Weiß M, Kunz J, Wolf G (2016) Incidence of osteoporotic fractures and fracture associated complications in Jena/Thuringia. Osteologie 25: 7-11.

Lemaire RG (1966) Calcium metabolism in fracture healing. An experimental kinetic study in rats, using Ca45. J Bone Joint Surg Am 48: 1156-1170.

Li YC, Amling M, Pirro AE, Priemel M, Meuse J, Baron R, Delling G, Demay MB (1998) Normalization of mineral ion homeostasis by dietary means prevents hyperparathyroidism, rickets, and osteomalacia, but not alopecia in vitamin $\mathrm{D}$ receptor-ablated mice. Endocrinology 139: 4391-4396.

Li YC, Pirro AE, Amling M, Delling G, Baron R, Bronson R, Demay MB (1997) Targeted ablation of the vitamin $\mathrm{D}$ receptor: an animal model of vitamin D-dependent rickets type II with alopecia. Proc Natl Acad Sci U S A 94: 9831-9835.

Lindgren JU, Narechania RG, McBeath AA, Lange TA, DeLuca HF (1981) Effects of 1,24 dihydroxyvitamin D3 and calcitonin on fracture healing in adult rats. Clin Orthop Relat Res: 304-308.

Lindsay R, Silverman SL, Cooper C, Hanley DA, Barton I, Broy SB, Licata A, Benhamou L, Geusens P, Flowers K, Stracke H, Seeman E (2001) Risk of new vertebral fracture in the year following a fracture. JAMA 285: 320-323.

Lips P, van Schoor NM (2011) The effect of vitamin D on bone and osteoporosis. Best Pract Res Clin Endocrinol Metab 25: 585-591.

Liu S, Tang W, Zhou J, Stubbs JR, Luo Q, Pi M, Quarles LD (2006) Fibroblast growth factor 23 is a counter-regulatory phosphaturic hormone for vitamin D. J Am Soc Nephrol 17: 1305-1315.

Lyles KW, Schenck AP, Colon-Emeric CS (2008) Hip and other osteoporotic fractures increase the risk of subsequent fractures in nursing home residents. Osteoporos Int 19: 1225-1233.

MacLaughlin J, Holick MF (1985) Aging decreases the capacity of human skin to produce vitamin D3. J Clin Invest 76: 1536-1538.

Matsumoto T, Igarashi C, Takeuchi Y, Harada S, Kikuchi T, Yamato H, Ogata E (1991) Stimulation by 1,25-dihydroxyvitamin D3 of in vitro mineralization induced by osteoblast-like MC3T3-E1 cells. Bone 12: 27-32.

McCormick CC (2002) Passive diffusion does not play a major role in the absorption of dietary calcium in normal adults. J Nutr 132: 3428-3430.

Melhus G, Solberg LB, Dimmen S, Madsen JE, Nordsletten L, Reinholt FP (2007) Experimental osteoporosis induced by ovariectomy and vitamin D deficiency does not markedly affect fracture healing in rats. Acta Orthop 78: 393-403.

Meller Y, Kestenbaum RS, Mozes M, Mozes G, Yagil R, Shany S (1984) Mineral and endocrine metabolism during fracture healing in dogs. Clin Orthop Relat Res: 289-295.

Meyer RA, Jr., Tsahakis PJ, Martin DF, Banks DM, Harrow ME, Kiebzak GM (2001) Age and ovariectomy impair both the normalization of mechanical properties and the accretion of mineral by the fracture callus in rats. J Orthop Res 19: 428-435.

Namkung-Matthai H, Appleyard R, Jansen J, Hao Lin J, Maastricht S, Swain M, Mason RS, Murrell GA, Diwan AD, Diamond T (2001) Osteoporosis influences the early period of fracture healing in a rat osteoporotic model. Bone 28: 80-86.

Nikolaou VS, Efstathopoulos N, Kontakis G, Kanakaris NK, Giannoudis PV (2009) The influence of osteoporosis in femoral fracture healing time. Injury 40: 663-668.

Nordin BE (1997) Calcium and osteoporosis. Nutrition 13: 664-686.

Omeroglu H, Ates Y, Akkus O, Korkusuz F, Bicimoglu A, Akkas N (1997a) Biomechanical analysis of the effects of single high-dose vitamin D3 on fracture healing in a healthy rabbit model. Arch Orthop Trauma Surg 116: 271-274.

Omeroglu S, Erdogan D, Omeroglu H (1997b) Effects of single high-dose vitamin D3 on fracture healing. An ultrastructural study in healthy guinea pigs. Arch Orthop Trauma Surg 116: 37-40.

Omsland TK, Emaus N, Tell GS, Ahmed LA, Center JR, Nguyen ND, Gjesdal CG, Forsmo S, Schei B, Sogaard AJ, Meyer HE (2013) Ten-year risk of second hip fracture. A NOREPOS study. Bone 52: 493-497.

Peacock M (2010) Calcium metabolism in health and disease. Clin J Am Soc Nephrol 5 Suppl 1: S23-30.

Peacock M, Liu G, Carey M, McClintock R, Ambrosius W, Hui S, Johnston CC (2000) Effect of calcium or $25 \mathrm{OH}$ vitamin D3 dietary supplementation on bone loss at the hip in men and women over the age of 60. J Clin Endocrinol Metab 85: 3011-3019.

Petersen MM, Gehrchen PM, Nielsen PK, Lund B (1997) Loss of bone mineral of the hip assessed by DEXA following tibial shaft fractures. Bone 20: 491495.

Pourfeizi HH, Tabriz A, Elmi A, Aslani H (2013) Prevalence of vitamin D deficiency and secondary hyperparathyroidism in nonunion of traumatic fractures. Acta Med Iran 51: 705-710.

Prentice A (2013) Standing on the shoulders of giants: Understanding calcium and vitamin D requirements. Nutrition Bulletin 38: 323-331.

Priemel M, von Domarus C, Klatte TO, Kessler S, Schlie J, Meier S, Proksch N, Pastor F, Netter C, Streichert T, Puschel K, Amling M (2010) Bone mineralization defects and vitamin $\mathrm{D}$ deficiency: histomorphometric analysis of iliac crest bone biopsies and circulating 25-hydroxyvitamin D in 675 patients. J Bone Miner Res 25: 305-312.

Rachner TD, Khosla S, Hofbauer LC (2011) Osteoporosis: now and the future. Lancet 377: 12761287. 
Robling AG, Castillo AB, Turner CH (2006) Biomechanical and molecular regulation of bone remodeling. Annu Rev Biomed Eng 8: 455-498.

Ryg J, Rejnmark L, Overgaard S, Brixen K, Vestergaard P (2009) Hip fracture patients at risk of second hip fracture: a nationwide population-based cohort study of 169,145 cases during 1977-2001. J Bone Miner Res 24: 1299-1307.

Sawalha S, Parker MJ (2012) Characteristics and outcome in patients sustaining a second contralateral fracture of the hip. J Bone Joint Surg Br 94: 102-106.

Schilling S (2012) Epidemic vitamin D deficiency among patients in an elderly care rehabilitation facility. Dtsch Arztebl Int 109: 33-38.

Schinke T, Schilling AF, Baranowsky A, Seitz S, Marshall RP, Linn T, Blaeker M, Huebner AK, Schulz A, Simon R, Gebauer M, Priemel M, Kornak U, Perkovic S, Barvencik F, Beil FT, Del Fattore A, Frattini A, Streichert T, Pueschel K, Villa A, Debatin KM, Rueger JM, Teti A, Zustin J, Sauter G, Amling M (2009) Impaired gastric acidification negatively affects calcium homeostasis and bone mass. Nat Med 15: 674-681.

Shimada T, Kakitani M, Yamazaki Y, Hasegawa H, Takeuchi Y, Fujita T, Fukumoto S, Tomizuka K, Yamashita T (2004) Targeted ablation of Fgf23 demonstrates an essential physiological role of FGF23 in phosphate and vitamin D metabolism. J Clin Invest 113: 561-568.

Shimada T, Mizutani S, Muto T, Yoneya T, Hino R, Takeda S, Takeuchi Y, Fujita T, Fukumoto S, Yamashita T (2001) Cloning and characterization of FGF23 as a causative factor of tumor-induced osteomalacia. Proc Natl Acad Sci U S A 98: 6500-6505.

Sprague S, Petrisor B, Scott T, Devji T, Phillips M, Spurr H, Bhandari M, Slobogean GP (2016) What is the role of vitamin D supplementation in acute fracture patients? A systematic review and meta-analysis of thep of hypovitaminosis D and supplementation efficacy. J Orthop Trauma 30: 53-63.

Suda T, Takahashi N, Udagawa N, Jimi E, Gillespie MT, Martin TJ (1999) Modulation of osteoclast differentiation and function by the new members of the tumor necrosis factor receptor and ligand families. Endocr Rev 20: 345-357.

Sun MH, Leung KS, Zheng YP, Huang YP, Wang LK, Qin L, Leung AH, Chow SK, Cheung WH (2012) Three-dimensional high frequency power Doppler ultrasonography for the assessment of microvasculature during fracture healing in a rat model. J Orthop Res 30: 137-143.

Tabatabaei-Malazy O, Salari P, Khashayar P, Larijani B (2017) New horizons in treatment of osteoporosis. Daru 25: 2. DOI: 10.1186/s40199-0170167-z.

Tang BM, Eslick GD, Nowson C, Smith C, Bensoussan A (2007) Use of calcium or calcium in combination with vitamin $\mathrm{D}$ supplementation to prevent fractures and bone loss in people aged 50 years and older: a meta-analysis. Lancet 370: 657-666.
Ulivieri FM, Bossi E, Azzoni R, Ronzani C, Trevisan C, Montesano A, Ortolani S (1990) Quantification by dual photonabsorptiometry of local bone loss after fracture. Clin Orthop Relat Res: 291-296.

Urakawa I, Yamazaki Y, Shimada T, Iijima K, Hasegawa H, Okawa K, Fujita T, Fukumoto S, Yamashita T (2006) Klotho converts canonical FGF receptor into a specific receptor for FGF23. Nature 444: 770-774.

van der Poest Clement E, van der Wiel H, Patka P, Roos JC, Lips P (1999) Long-term consequences of fracture of the lower leg: cross-sectional study and long-term longitudinal follow-up of bone mineral density in the hip after fracture of lower leg. Bone 24: 131-134.

Van der Wiel HE, Lips P, Nauta J, Patka P, Haarman HJ, Teule GJ (1994) Loss of bone in the proximal part of the femur following unstable fractures of the leg. J Bone Joint Surg Am 76: 230-236.

van Driel M, Koedam M, Buurman CJ, Hewison M, Chiba H, Uitterlinden AG, Pols HA, van Leeuwen JP (2006) Evidence for auto/paracrine actions of vitamin D in bone: 1alpha-hydroxylase expression and activity in human bone cells. FASEB J 20: 24172419.

van Leeuwen JP, Pols HA, Schilte JP, Visser TJ, Birkenhager JC (1991) Modulation by epidermal growth factor of the basal 1,25(OH)2D3 receptor level and the heterologous up-regulation of the $1,25(\mathrm{OH}) 2 \mathrm{D} 3$ receptor in clonal osteoblast-like cells. Calcif Tissue Int 49: 35-42.

Veitch SW, Findlay SC, Hamer AJ, Blumsohn A, Eastell R, Ingle BM (2006) Changes in bone mass and bone turnover following tibial shaft fracture. Osteoporos Int 17: 364-372.

von Domarus C, Brown J, Barvencik F, Amling M, Pogoda P (2011) How much vitamin D do we need for skeletal health? Clin Orthop Relat Res 469: 31273133.

von Ruden C, Augat P (2016) Failure of fracture fixation in osteoporotic bone. Injury 47 Suppl 2: S3S10.

Wakimoto P, Block G (2001) Dietary intake, dietary patterns, and changes with age: an epidemiological perspective. J Gerontol A Biol Sci Med Sci 56 Spec No 2: $65-80$.

Wang JW, Li W, Xu SW, Yang DS, Wang Y, Lin M, Zhao GF (2005) Osteoporosis influences the middle and late periods of fracture healing in a rat osteoporotic model. Chin J Traumatol 8: 111-116.

Wang Y, Zhu J, DeLuca HF (2014) Identification of the vitamin $D$ receptor in osteoblasts and chondrocytes but not osteoclasts in mouse bone. J Bone Miner Res 29: 685-692.

Warensjo E, Byberg L, Melhus H, Gedeborg R, Mallmin H, Wolk A, Michaelsson K (2011) Dietary calcium intake and risk of fracture and osteoporosis: prospective longitudinal cohort study. BMJ 342: DOI: 10.1136/bmj.d1473.

Warner SJ, Garner MR, Nguyen JT, Lorich DG (2016) Perioperative vitamin D levels correlate with 
clinical outcomes after ankle fracture fixation. Arch Orthop Trauma Surg 136: 339-344.

Weaver J, Sajjan S, Lewiecki EM, Harris ST (2017) Diagnosis and treatment of osteoporosis before and after fracture: a side-by-side analysis of commercially insured and medicare advantage osteoporosis patients. J Manag Care Spec Pharm 23: 735-744.

Webb AR, Kline L, Holick MF (1988) Influence of season and latitude on the cutaneous synthesis of vitamin D3: exposure to winter sunlight in Boston and Edmonton will not promote vitamin D3 synthesis in human skin. J Clin Endocrinol Metab 67: 373-378.

Weber TJ, Liu S, Indridason OS, Quarles LD (2003) Serum FGF23 levels in normal and disordered phosphorus homeostasis. J Bone Miner Res 18: 12271234.

Wehrle E, Liedert A, Heilmann A, Wehner T, Bindl R, Fischer L, Haffner-Luntzer M, Jakob F, Schinke T, Amling M, Ignatius A (2015) The impact of lowmagnitude high-frequency vibration on fracture healing is profoundly influenced by the oestrogen status. Dis Model Mech 8: 93-104.

Westlin NE (1974) Loss of bone mineral after Colles' fracture. Clin Orthop Relat Res: 194-199.

Woeckel VJ, Alves RD, Swagemakers SM, Eijken M, Chiba H, van der Eerden BC, van Leeuwen JP (2010) 1Alpha,25-(OH)2D3 acts in the early phase of osteoblast differentiation to enhance mineralization via accelerated production of mature matrix vesicles. J Cell Physiol 225: 593-600.

Wright NC, Looker AC, Saag KG, Curtis JR, Delzell ES, Randall S, Dawson-Hughes B (2014) The recent prevalence of osteoporosis and low bone mass in the United States based on bone mineral density at the femoral neck or lumbar spine. J Bone Miner Res 29: 2520-2526.

Xu H, Duan J, Ning D, Li J, Liu R, Yang R, Jiang JX, Shang P (2014) Role of Wnt signaling in fracture healing. BMB Rep 47: 666-672.

Xu SW, Wang JW, Li W, Wang Y, Zhao GF (2004) [Osteoporosis impairs fracture healing of tibia in a rat osteoporotic model]. Zhonghua Yi Xue Za Zhi 84: 1205-1209.

Yamada Y, Ando F, Niino N, Shimokata H (2005) Association of polymorphisms of the androgen receptor and klotho genes with bone mineral density in Japanese women. J Mol Med (Berl) 83: 50-57.

Yamazaki Y, Okazaki R, Shibata M, Hasegawa Y, Satoh K, Tajima T, Takeuchi Y, Fujita T, Nakahara K, Yamashita T, Fukumoto S (2002) Increased circulatory level of biologically active full-length FGF-23 in patients with hypophosphatemic rickets/ osteomalacia. J Clin Endocrinol Metab 87: 4957-4960.

Yu-Yahiro JA, Michael RH, Dubin NH, Fox KM, Sachs M, Hawkes WG, Hebel JR, Zimmerman SI, Shapiro J, Magaziner J (2001) Serum and urine markers of bone metabolism during the year after hip fracture. J Am Geriatr Soc 49: 877-883.

Zarei A, Morovat A, Javaid K, Brown CP (2016) Vitamin $\mathrm{D}$ receptor expression in human bone tissue and dose-dependent activation in resorbing osteoclasts. Bone Res 4: 16030. DOI: 10.1038/ boneres.2016.30.

Zarrabeitia MT, Hernandez JL, Valero C, Zarrabeitia AL, Ortiz F, Gonzalez-Macias J, Riancho JA (2007) Klotho gene polymorphism and male bone mass. Calcif Tissue Int 80: 10-14.

Zhao JG, Zeng XT, Wang J, Liu L (2017) Association between calcium or vitamin $\mathrm{D}$ supplementation and fracture incidence in community-dwelling older adults:a systematic review and meta-analysis. JAMA 318: 2466-2482.

Zura R, Xiong Z, Einhorn T, Watson JT, Ostrum RF, Prayson MJ, Della Rocca GJ, Mehta S, McKinley T, Wang Z, Steen RG (2016) Epidemiology of fracture nonunion in 18 human bones. JAMA Surg 151: e162775. DOI: 10.1001/jamasurg.2016.2775.

\section{Web reference}

1. https:// w w w a s b m r.org/ ASBMRStatementsDetail/recent-jama-studyquestioning-benefits-of-vitamin- [06-06-2018]

\section{Discussion with Reviewer}

Richard Stange: It would be of interest to know about fracture healing during pregnancy. Probably a rare event, but a challenging situation.

Authors: Due to increasing calcium needs required for the foetus skeletal development and to meet their own calcium needs, pregnant females must provide a sufficient amount of $1000 \mathrm{mg}$ of calcium per day (Kovacs, 2014, additional reference). This calcium demand is nearly met by an increase in calcium absorption efficiency of around $50 \%$ starting from the third month (Kovacs and Kronenberg, 1997; Kovacs, 2011, additional references). However, the maternal skeleton also serves as a calcium reservoir. Clinical studies report increased levels of bone resorption markers and marginally reduced bone mass in pregnant as compared to non-pregnant females. However, osteoporosis and fractures rarely occur during pregnancy (Kovacs, 2011; Purdie et al., 1988; Moller et al., 2012, additional references). Herath et al. (2017) report in a retro-prospective study that out of 114,673 pregnant females 33 sustain a fracture, with an ankle fracture as the most common one. Nevertheless, during conditions of additional calcium demand, as in the case of a fracture event plus insufficient calcium and vitamin D supply, bone resorption and bone loss might be increased. Based on previous findings (Fischer et al., 2017), it can be assumed that during fracture healing of pregnant females with additional calcium and/or vitamin D deficiency, the calcium needed for foetal development and fracture callus mineralisation might be increasingly mobilised from the intact skeleton through an 
increase in parathyroid hormone levels. Thus, fracture healing will be undisturbed, but increased bone resorption will reduce intact bone mass. Based on our knowledge, there are no experimental and clinical studies available investigating fracture healing outcome during pregnancy. There are only a few case reports outlining fracture healing in healthy pregnant females, with one showing even accelerated fracture union (Hadji et al., 2017; Herath et al., 2017; Tv et al., 2015, additional references). However, none of these reports investigate if there are changes also in the remaining skeleton. Long-term consequences of fractures during pregnancy are not known so far and should be considered in the future. Based on a search of the literature as well as previous findings, it is recommended that pregnant females, especially calcium- and vitamin-D-deficient ones, who suffer a fracture, should consume calcium and vitamin $\mathrm{D}$, at least during the fracture healing time course, to prevent skeletal bone loss. This aspect was not included in the discussion of the subject because published evidence is scarce.

\section{Additional references}

Kovacs CS (2011) Calcium and bone metabolism disorders during pregnancy and lactation. Endocrinol Metab Clin North Am 40: 795-826.

Kovacs CS (2014) Bone development and mineral homeostasis in the fetus and neonate: roles of the calciotropic and phosphotropic hormones. Physiol Rev 94: 1143-1218.

Kovacs CS, Kronenberg HM (1997) Maternal-fetal calcium and bone metabolism during pregnancy, puerperium, and lactation. Endocr Rev 18: 832-872.

Hadji P, Boekhoff J, Hahn M, Hellmeyer L, Hars O, Kyvernitakis I (2017) Pregnancy-associated osteoporosis: a case-control study. Osteoporos Int 28: 1393-1399.

Herath M, Wong P, Trinh A, Allan CA, Wallace EM, Ebeling PR, Fuller PJ, Milat F (2017) Minimal-trauma ankle fractures predominate during pregnancy: a 17-year retrospective study. Arch Osteoporos 12: 86. DOI: 10.1007/s11657-017-0380-x.

Purdie DW, Aaron JE, Selby PL (1988) Bone histology and mineral homeostasis in human pregnancy. Br J Obstet Gynaecol 95: 849-854.

Moller UK, Vieth Streym S, Mosekilde L, Rejnmark L (2012) Changes in bone mineral density and body composition during pregnancy and postpartum. A controlled cohort study. Osteoporos Int 23: 1213-1223.

Tv R, P R, Grover A, Samorekar B (2015) Bilateral distal radius fracture in third trimester of pregnancy with accelerated union: a rare case report. J Clin Diagn Res 9: RD01-02. DOI:10.7860/JCDR/2015/11498.5751.

Editor's note: The Scientific Editor responsible for this paper was Juerg Gasser. 